\title{
Rapid and simple prenatal diagnosis of common chromosome disorders: advantages and disadvantages of the molecular methods FISH and QF-PCR
}

\author{
Maj A. Hultén ${ }^{1}$, Seema Dhanjal ${ }^{1}$ and Barbara Pertl ${ }^{2}$ \\ ${ }^{1}$ Department of Biological Sciences, University of Warwick, Coventry CV4 7AL, UK; and ${ }^{2}$ Department of \\ Obstetrics and Gynaecology, University of Graz, Austria
}

\begin{abstract}
Molecular techniques have been developed for prenatal diagnosis of the most common chromosome disorders (trisomies 21, 13, 18 and sex chromosome aneuploidies) where results are available within a day or two. This involves fluorescence in situ hybridization (FISH) and microscopy analysis of fetal cells or quantitative fluorescence polymerase chain reaction (QF-PCR) on fetal DNA. Guidance is provided on the technological pitfalls in setting up and running these methods. Both methods are reliable, and the risk for misdiagnosis is low, although slightly higher for FISH. FISH is also more labour intensive than QF-PCR, the latter lending itself more easily to automation. These tests have been used as a preamble to full chromosome analysis by microscopy. However, there is a trend to apply the tests as 'stand-alone' tests for women who are at relatively low risk of having a baby with a chromosome disorder, in particular that associated with advanced age or results of maternal serum screening programmes. These women comprise the majority of those currently offered prenatal diagnosis with respect to fetal chromosome disorders and if introduced on a larger scale, the use of FISH and QF-PCR would lead to substantial economical savings. The implication, on the other hand, is that around one in 500 to one in 1000 cases with a mentally and/or physically disabling chromosome disorder would remain undiagnosed.
\end{abstract}

Prenatal diagnosis with a view to identifying fetal genetic disorders started in the early 1970s. Since its inception, the most common reason for prenatal diagnosis is increased risk of having a child with trisomy 21 Down syndrome. This risk is dependent on maternal age, and is also assessed by maternal serum screening programmes and fetal ultrasonography (nuchal translucency). Other indications for prenatal diagnosis of chromosome disorders include additional structural fetal abnormalities detected by ultrasonography, a previous child with a chromosome disorder or either parent being a carrier of a chromosomal rearrangement.

Over the years prenatal diagnosis has become increasingly common; for example, to date it involves around 1 in 20 pregnant women in the UK. Fetal cells for chromosome diagnosis are obtained either by amniocentesis (usually at about 15 weeks of gestation) or chorionic villus sampling (at about 9-11 weeks of gestation). Both these procedures are invasive and carry an associated risk for induced abortion in approximately 1 in 100 to 1 in 200 women tested. Traditionally, chromosome diagnosis

Email: maj.hulten@warwick.ac.uk is accomplished by karyotyping, that is, analysis of chromosomes by microscopy followed by the lining up of each chromosome pair (Fig. 1).

Karyotyping, most often by Giemsa banding (Gbanding) is performed on fetal cells at the metaphase stage of the cell cycle, when chromosomes are optimally condensed. Amniotic fluid samples obtained by amniocentesis do not contain any fetal cells in division and have to be grown in vitro to obtain cells at the metaphase stage. In chorionic villus samples (CVSs), some fetal cells are spontaneously dividing and cells at metaphase can be used. However, the resolution (of special importance for the detection of structural abnormalities) may be quite low, as these spontaneously dividing cells have more condensed chromosomes than those obtained after cell culture in vitro. Another disadvantage of CVSs is the common occurrence of confined placental mosaicism, the occurrence of a proportion of aberrant cells that do not represent the chromosome status of the fetus. These aberrant cells when originating in cytotrophoblasts may be selected against during cell culture in vitro. Therefore, cell culture is usually performed as a follow-up to any direct chromosome diagnosis on CVSs. 


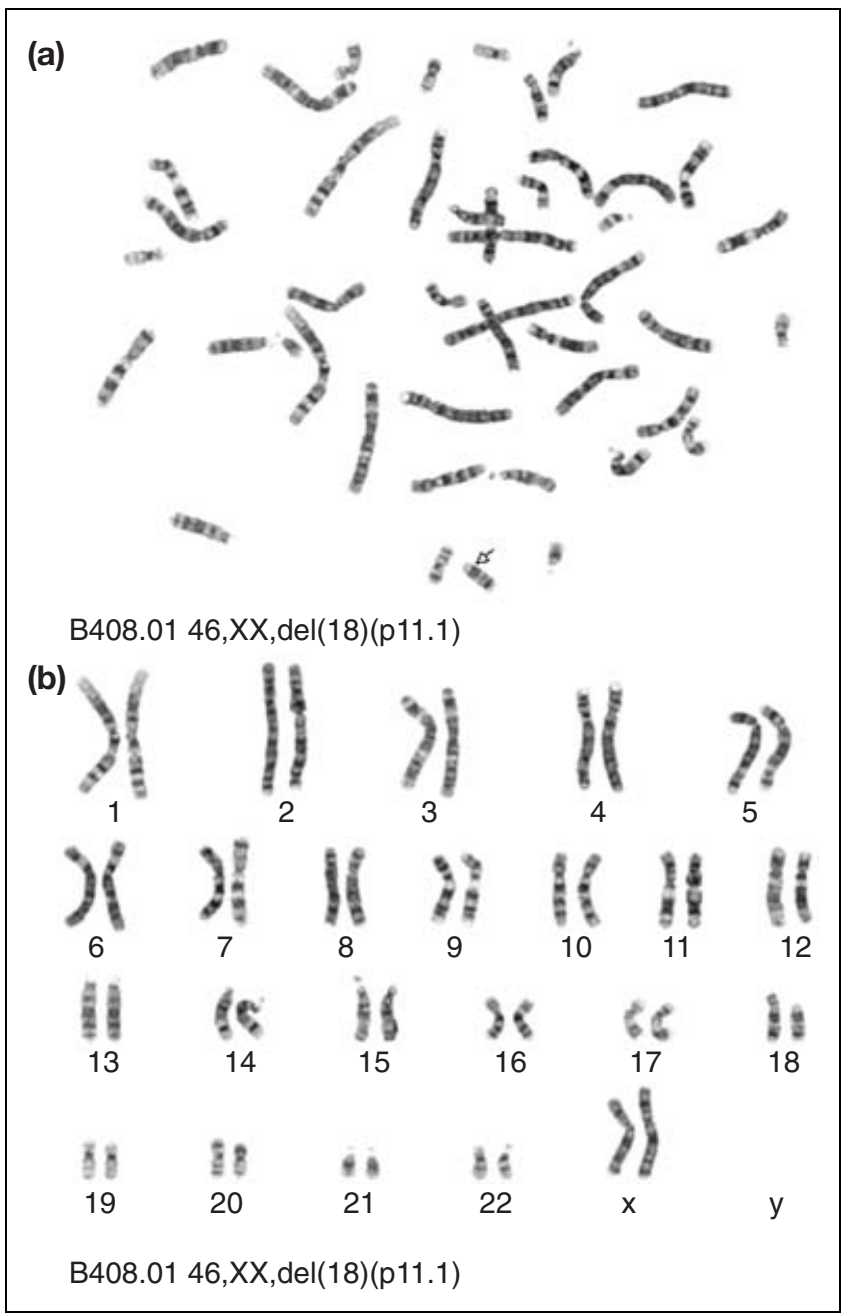

Fig. 1. G-banded chromosomes from a female with an $18 p$ deletion and the $\mathrm{XX}$ sex chromosome constitution. The deletion (arrow) involves about $25 \mathrm{Mb}$ of DNA. (a) Metaphase plate and (b) the corresponding karyotype.

During the last three decades, improved technology for prenatal diagnosis by karyotyping has mainly involved devising methods for obtaining less condensed chromosomes and for reducing culture time.

The presence of a larger number of bands on longer chromosomes implies that subtler structural chromosome abnormalities may be detected. However, it is important to note that even at high resolution G-banding, deletions or duplications $<5 \mathrm{Mb}$ will usually remain undetected. The implication is that a proportion of chromosome abnormalities, which may be associated with physical and mental disability, will not be routinely diagnosed, even with this 'gold standard' test.

In the early days, it took around 3-4 weeks of culture of amniocytes in vitro to obtain enough cells in division for karyotyping but substantial reduction in culture time of both amniocytes and chorionic villus cells has been achieved more recently. For example, from 1987 to 1998 , the average reporting time in the UK decreased from 20.2 to 13.8 days for amniotic fluid samples and from 21.3 to 14.5 days for CVSs (Waters and Waters, 1999). Some laboratories have been able to reduce the culture time in vitro even further (for example, see Miller and Peakman, 1999).

It is recognized that long waiting times for results may cause much psychological suffering and this has been one of the main reasons for the introduction of molecular methods for prenatal diagnosis of common chromosome disorders. This type of approach does not require cell culture and reports can routinely be issued within 1-2 days.

\section{Provision of rapid and simple detection of common fetal chromosome disorders}

The two most common types of molecular method for prenatal diagnosis of chromosome disorders are fluorescence in situ hybridization (FISH) and the quantitative fluorescence polymerase chain reaction $(\mathrm{QF}-$ PCR). Both methods are now used routinely for rapid and simple diagnosis of aneuploidy (numerical chromosome abnormalities), including in particular trisomy 21, 13 and 18 (giving rise to the Down, Patau and Edward syndromes, respectively) and sex chromosome abnormalities (associated with the XXY-Klinefelter, XYY, XXX and $X$-Turner syndromes). The disorders listed above are the most common. Overall they comprise $70-80 \%$ of karyotyped abnormalities associated with physical-mental handicap. However, they constitute $99.8-99.9 \%$ in lowrisk pregnancies, in which women are tested because of maternal age, maternal serum or ultrasonographic screening for fetal nuchal translucency (for example, see Ward et al., 1993; Evans et al., 1999; Pergament et al., 2000; Thein et al., 2000; Grimshaw et al., 2003). Notably, there is some variation among studies, and a much higher rate of residual abnormality has been identified in a recent study by Homer et al. (2003).

\section{FISH and QF-PCR involve DNA fluorescence but in different ways}

FISH and QF-PCR both make use of fluorescence tagging of DNA, but chromosome diagnosis is accomplished by each in very different ways.

\section{FISH}

FISH involves hybridization of selected chromosomespecific DNA sequences that have been labelled with fluorescent dyes to chromosome preparations. The fluorescently labelled sequences stick to the corresponding DNA of the chromosomes and can be visualized under the microscope (for review, see Lichter and Cremer, 


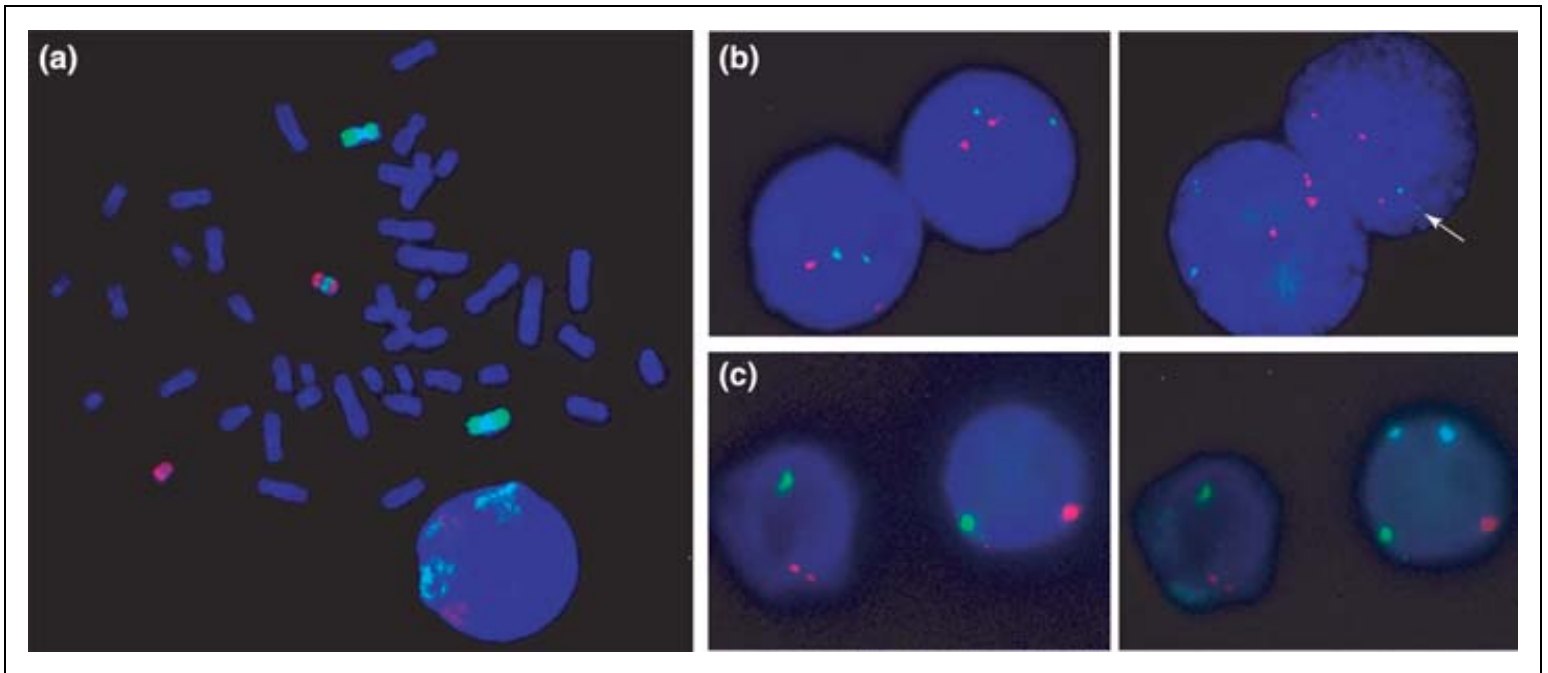

Fig. 2. Fluorescence in situ hybridization (FISH) images of metaphase and interphase nuclei. (a) Metaphase plate and interphase nuclei from a female carrier of an insertion of a segment of chromosome 20 into chromosome 9. Labelling with whole chromosome FISH probes specific for chromosome 9 (green) and chromosome 20 (red). Note that, in the metaphase, the chromosomes are distinctive but, in the interphase nuclei, they appear as fuzzy clouds. (b) FISH images of interphase nuclei from uncultured amniocytes hybridized with probes specific for chromosomes 21 and 13. In the normal case (left), there are two clear red signals corresponding to the two copies of chromosome 21 and two green signals corresponding to chromosome 13. In the trisomy 21 case (right), there are three clear red signals in both interphase nuclei, indicating the presence of an extra copy of chromosome 21. Note the split red signal, which could cause problems in interpreting the number of chromosomes present. By convention, a score as a single chromosome spot is assigned if the distance between spots is smaller than their size in any focal plane. Note also that one of the green signals is much smaller than the other (arrow), in this case indicating that the chromosome is lying in a different focal plane. Thus, it is very important to focus up and down when analysing interphase nuclei for aneuploidy diagnosis by microscopy. (c) FISH images of interphase nuclei from uncultured amniocytes from a normal male, hybridized with chromosome 18, $X$ and $Y$ probes. The image on the left shows the $\mathrm{X}$ - and $\mathrm{Y}$-chromosomes in green and red, respectively, indicating a normal XY male. The image on the right shows the same nuclei with the chromosome 18 signals in aqua. Note that, as the left nucleus is out of focus, the $Y$ signal appears split and the chromosome 18 spots are very diffuse and hardly identifiable.

2001). The first developed probes were derived from DNA of flow-sorted whole chromosomes and used for prenatal diagnosis of trisomy 21, 13 or 18 by Kuo et al (1991) on uncultured amniotic fluid cell nuclei. The drawback of this approach is that the signals obtained may be quite diffuse, as chromosomes at interphase of the cell cycle often appear much less condensed than those at metaphase, if standard fixation technologies are used (Fig. 2a). For aneuploidy diagnosis, FISH with smaller probes is advantageous, as signals appear as more distinct dots. Normal samples are expected to show two dots per cell nucleus, whereas those that are trisomic will show three dots (Fig. 2b,c). Initially, a variety of such probes was developed in research laboratories. More recently, probe sets have been produced commercially (Vysis) and are applied in batches, highlighting chromosomes 13 and 21 in one hybridization and 18 plus $X$ and $Y$ in another.

It should be noted that whole chromosome paints may in fact be successfully used, measuring the fluorescence ratio between a target chromosome in relation to a standard of similar size, not likely to be represented as a trisomy at the time of prenatal diagnosis (Truong et al., 2003).

\section{QF-PCR}

The most common type of QF-PCR involves the amplification of chromosome-specific, repeated DNA sequences known as small (short) tandem repeats (STRs). STRs are stable and polymorphic, that is, they vary in length between subjects, depending on the number of times the tri-, tetra- or penta-nucleotides are repeated. The sample DNA is amplified by PCR using fluorescent primers so that products can be visualized and quantified as peak areas of the respective repeat lengths using an automated DNA sequencer with the Gene-Scan software (Fig. 3). DNA amplified from normal subjects who are heterozygous (have alleles of different lengths) is expected to show two peaks with the same area. DNA amplified from subjects who are trisomic will exhibit either an extra peak (being triallelic) with the same area, or only two peaks (being diallelic), one of them twice as large as the other. By convention (agreed at a Symposium 


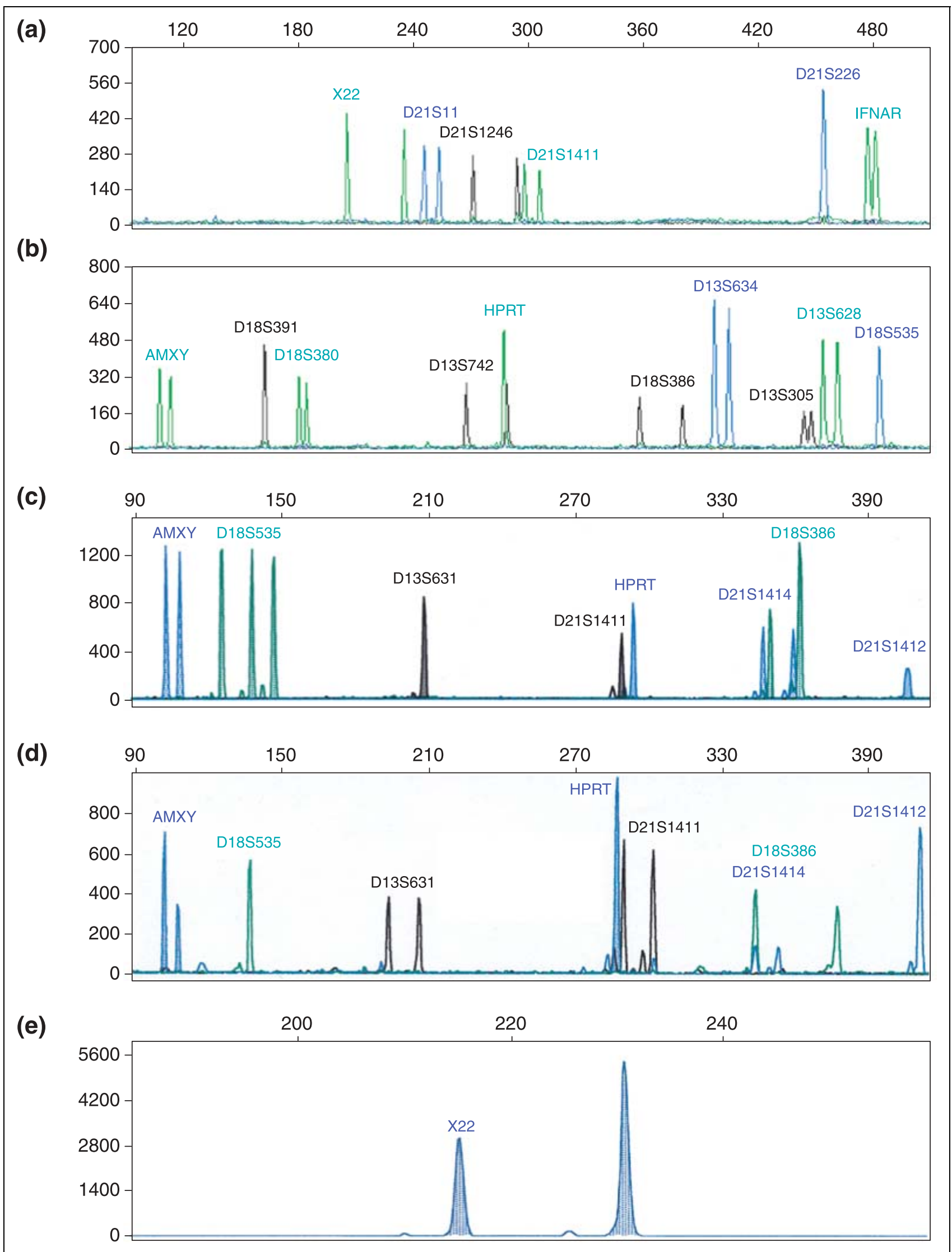

Fig. 3. For caption see facing page. 


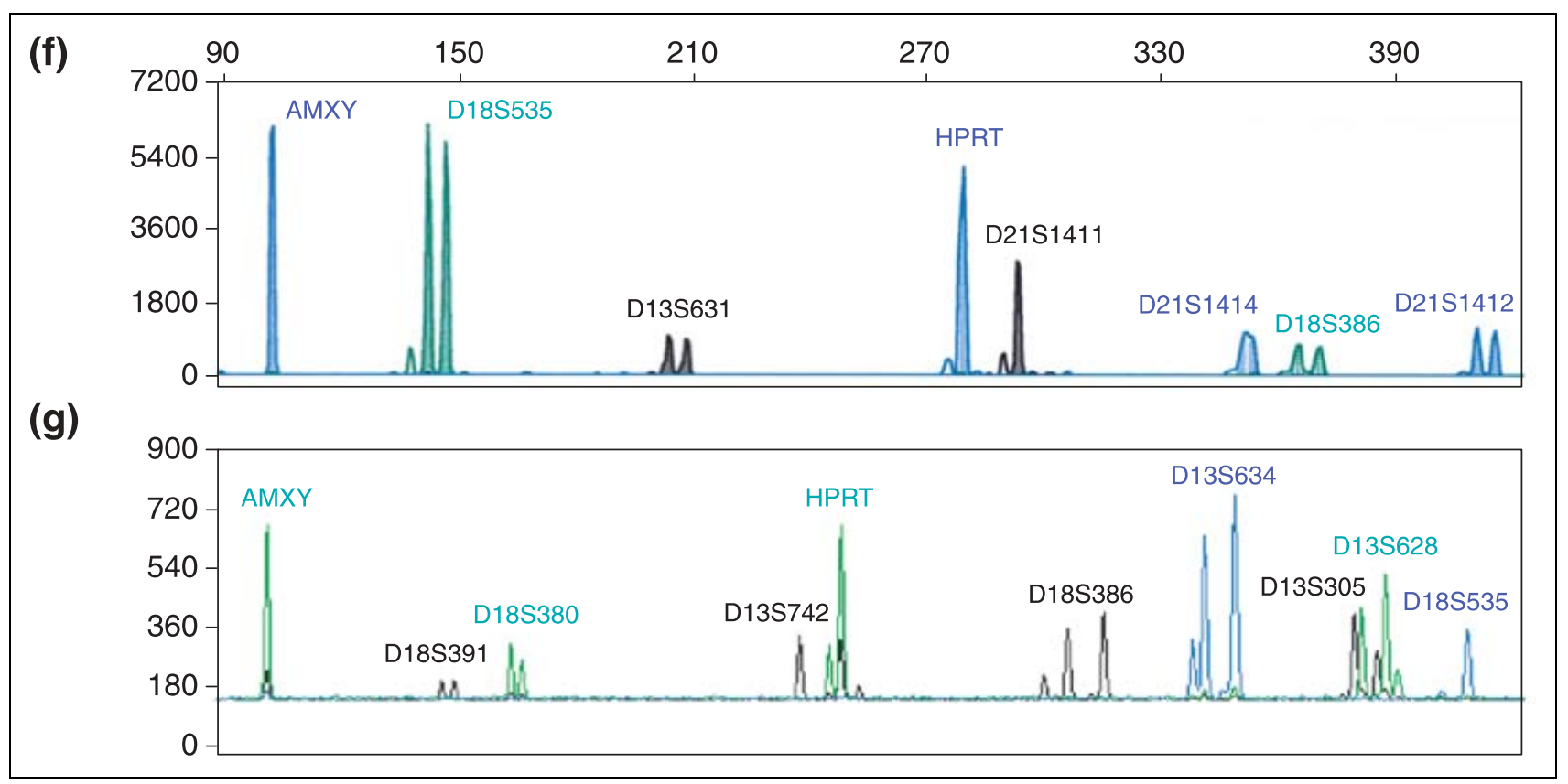

Fig. 3. Electrophoretograms of QF-PCR amplifications. The $x$-axis shows the length of the PCR products in base pairs and the $y$-axis shows the fluorescence intensity in arbitrary units. (a) DNA sample from a normal subject amplified with X22 (green), and 5 markers for chromosome 21: D21S11 (blue), D21S1246 (black), D21S1411 (green), D21S226 (blue) and IFNAR (green). Except for D21S226, which is homozygous, all the 21 markers are heterozygous, with two peaks of nearly 1:1 ratio. (b) DNA sample from the same subject amplified with four markers each for chromosomes 13 and 18 and AMXY and HPRT for the sex chromosomes. AMXY (green) indicates a 46,XY male, HPRT (green) is uninformative showing homozygosity, D18S391 (black) is also uninformative showing homozygosity, D18S380 (green) is informative showing heterozygosity with two peaks of nearly 1:1 ratio, D18S386 (black) is also informative showing heterozygosity with two peaks of nearly 1:1 ratio, D18S535 (blue) and D13S742 (black) are uninformative showing homozygosity, whereas D13S634 (blue), D13S305 (black) and D13S628 (green) are informative showing heterozygosity with two peaks of nearly 1:1 ratios. (c) DNA sample from a trisomy 18 case amplified with AMXY (blue), D18S535 (green), D13S631 (black), HPRT (blue), D21S1411 (blue), D18S386 (green) and D21S1412 (blue) in a single multiplex reaction. D18S535 displays triallelic trisomic pattern with three peaks of approximately 1:1:1 ratio, whereas D18S386 shows the diallelic ratio of 0.56 within the trisomic range. (d) DNA sample from a suspected 47,XXY (Klinefelter syndrome) case amplified with the same markers as in (c). A modified version of the AMXY is used, showing a 2:1 ratio for X:Y indicating the XXY constitution. As HPRT is homozygous, no definite conclusion can be derived unless the sample is re-amplified with additional $X$ - and $Y$-chromosome-specific markers, showing heterozygosity. (e) Same sample as in (d), amplified with the X22 marker, displaying two peaks with a 2:1 ratio confirming the XXY status. (f) Example of suspected 45,X (Turner syndrome). DNA amplified with the markers as in (c), showing only one peak for AMXY and one for HPRT, hence making it difficult to differentiate between a normal female homozygous for HPRT and a 45,X Turner case. Therefore, the DNA of this case has to be amplified with additional $X$ - and $Y$-chromosome-specific markers for reliable diagnosis. (g) Example of maternal contamination showing multiple triallelic peaks outside the 1:1:1 ratio, precluding reliable diagnosis on fetal aneuploidy.

in Austria in 2001 arranged by Barbara Pertl), samples that are diallelic, containing two peaks with area ratios of the shorter and the longer allele within the range 0.81.4 , are considered to be normal. In contrast, diallelic samples with ratios $<0.65$ or $>1.8$, are considered to be trisomic (for examples, see Fig.3a-c).

STRs that are highly polymorphic have been commonly used as markers for QF-PCR. However, single nucleotide polymorphisms (SNPs), which are much more frequent in the human genome, present an alternative option, likely to become more commonly applied in future. In addition, unique DNA sequences may be applied, for example using the novel multiplex ligation-dependent probe amplification (MLPA) technique (Schouten et al., 2002).

\section{FISH requires larger samples and is more labour intensive than QF-PCR}

\section{FISH}

Aneuploidy diagnosis by FISH is performed on preparations made from around $1.0-1.5 \mathrm{ml}$ of amniotic fluid. After centrifugation, cells in the pellet are fixed and placed on microscopy slides and hybridized with FISH probes (Klinger et al., 1992). Samples may be handled in batches but the process is still quite time consuming (Grimshaw et al., 2003). Some reduction in time may be achieved by the use of automatic harvesters (for example, Hamilton). The most time-consuming part of the interphase FISH procedure concerns fluorescence microscopy, and involves spot counting of 25-50 nuclei with 
Table 1. Apparently false positive and false negative fluorescence in situ hybridization (FISH) signals per 1000 interphase nuclei in amniotic fluid samples diagnosed by karyotyping as normal (non-mosaic) $46, \mathrm{XX}$ or $46, \mathrm{XY}$

\begin{tabular}{llllll}
\hline & $X$ & $Y$ & 21 & 13 & 18 \\
\hline False positive & 7 & 0.6 & 20 & 12 & 17 \\
False negative & 6 & 2 & 30 & 32 & 39 \\
\hline
\end{tabular}

A total of 353 cases was analysed comprising in total 18060 interphase nuclei.

respect to chromosomes 21 and 13 in one batch, and chromosomes 18, $\mathrm{X}$ and $\mathrm{Y}$ in another. This is expected to take about 30 min per sample. A relatively large number of cells is analysed, as a proportion of normal nuclei may show either a missing (false negative) or an extra (false positive) signal (Table 1). Some laboratories are routinely counting around 100 cells in order to increase the chance of detecting constitutional mosaicism (see below). Several firms are developing image analysis software for automated spot counting (for example, Applied Imaging, Bioview, Imstar and Metasystems) but as yet there are no published reports on their accuracy or efficiency in terms of labour saved.

\section{$Q F-P C R$}

QF-PCR can accommodate smaller sized samples than are required for FISH for prenatal aneuploidy diagnosis. Routinely, DNA is extracted in batches from about $0.5-1.0 \mathrm{ml}$ amniotic fluid per case, taken at about 15 weeks, followed by PCR amplification and gel electrophoresis on a DNA sequencer. An alternative option involves sampling the exo-coelomic fluid, which can take place much earlier, at 5 weeks (Jauniaux et al., 2003). The analysis when carried out by the Gene-Scan software on an automated DNA sequencer (for example, Applied Biosystems) is expected to take about $5 \mathrm{~min}$ per sample. QF-PCR is more amenable to automation than $\mathrm{FISH}$, and a large number of samples can be handled simultaneously, allowing substantial economy of scale (Grimshaw et al., 2003).

The markers, specific for chromosomes $21,13,18, X$ and $Y$ that have been used for QF-PCR, together with their heterozygosity, are exemplified (Table 2). Original studies applied one marker at a time but several more recent reports describe the development of multiplex assays in which 4-12 markers are co-amplified in different combinations (Table 3). Most often 1-3 multiplex assays are used for aneuploidy diagnosis with a minimum of two informative markers per chromosome required for confident diagnosis. Samples that are uninformative (or suspected to be abnormal) may be re-tested, using additional markers as a back-up.

In our view, the most taxing part of setting up a QFPCR service for prenatal interphase diagnosis concerns optimization of the primers to be included in any one multiplex reaction. To date, there are no commercial STR multiplex primer kits available.

\section{The risk for misdiagnosis by either FISH or QF-PCR is relatively small}

\section{FISH}

There are now a large number of reports in the literature highlighting the efficacy of rapid prenatal aneuploidy diagnosis, using FISH probes on interphase nuclei. The experience gained so far with respect to the proportion of cases that are informative, and the risk for misdiagnosis, is summarized (Table 4).

Some DNA sequences may be shared in common between different centromeres, and the initial FISH probes developed for certain centromeres cross-hybridized to others leading to diagnostic failures. The development of chromosome-specific probes, using unique DNA sequences has, to a large extent, eliminated this type of problem. Remaining diagnostic problems seen with the commercially available probe sets for chromosomes $21,13,18, \mathrm{X}$ and $\mathrm{Y}$ include, in particular, constitutional heteromorphisms leading to false positive or false negative results (Table 5).

The first prospective FISH study on interphase amniocytes, using probes for single copy-like signals of chromosomes 21, 18, 13, $\mathrm{X}$ and $\mathrm{Y}$ appeared more than a decade ago (Klinger et al., 1992). This seminal investigation was followed only a year later by another (and much larger) prospective study involving 4500 samples, showing $90.2 \%$ informativeness when using region-specific probes for the same chromosomes (Ward et al., 1993).

Many more recent literature reports have indicated a much higher informativeness. They also show that the risk of either over- or underdiagnosis of anueploidy for the target chromosomes is small by interphase FISH, using the 'gold standard' of karyotyping as a comparison (Table 4). One recent review summarizes data on 29039 cases (Tepperberg et al., 2001). On the basis of their most recent series of 5197 informative tests, using the Aneuvysion probe set (Vysis), the authors predict a risk for a false positive result to be less than 1 in 30000 cases and that of a false negative to be less than 1 in 4000. However, not all centres agree. Thus, for example, Weremowicz et al. (2001) comment that, in their experience, the sensitivity (the probability that the FISH test will accurately predict karyotypic aneuploidy) and specificity (the probability that the FISH test will accurately predict karyotypic normality) is much lower (Table 4). It should be added that some discrepancies might in fact be expected between uncultured and cultured cell populations, particularly with respect to maternal cell contamination and mosaic cell lines. The reason for this is that during cell proliferation in vitro, 
some cell types may be preferentially selected against and thus lost for karyotyping.

\section{QF-PCR}

The first QF-PCR application involved X chromosome aneuploidy (Lubin et al., 1991). This was followed by investigation of the trisomies 21, 13 and 18 in a relatively small number of cases in single or multiplex PCR reactions (Mansfield, 1993; Pertl et al., 1994; Adinolfi et al., 1995). More recently, a number of reports on larger series have been published (Table 3). Several other smaller studies confirm the high reliability and reproducibility of the QF-PCR assay (Findlay et al., 1998; Pertl et al., 1999; Yang et al., 1999; Chen et al., 2000; Bili et al., 2002). False negative or false positive results using QF-PCR are rare, in particular when analysing autosomal chromosomes. The main problem QFPCR has posed is when testing for sex chromosome abnormalities. When STRs specific for chromosome $X$ are used, some samples from normal XX females may show homozygous QF-PCR patterns, indistinguishable from those produced by samples with a single $X$, as in Turner syndrome (Fig. 3f). Incorporating additional $\mathrm{X}$-chromosome markers into the analysis will reduce the likelihood of homozygosity. Cirigliano et al. (2002) further suggested that the addition of an autosomal marker (such as D21S1411) as an internal control for quantification of the X-chromosome marker HPRT may solve the problem.

It is important to note that the occurrence of an extra or missing signal (or abnormal ratios) for a single marker in an otherwise normal multiplex reaction may not necessarily represent a technical artefact. There is a possibility that this could be caused by a fetal constitutional duplication or deletion of the chromosome segment, where the marker is localized. In this situation, it is advisable to check the same in DNA from parental blood samples. It may also be prudent to test adjacent markers to identify the size of the suspected duplication or deletion, which may either constitute a harmless polymorphism or be associated with mental and/or physical handicap.

\section{Maternal cell contamination may constitute more of a problem with FISH than with QF-PCR}

It has been estimated that a large proportion of amniotic fluid samples $(21.4 \%)$ is contaminated with some maternal cells. However, a much lower proportion (1-2\%) is macroscopically blood stained, potentially leading to false negative diagnosis of fetal aneuploidy (Winsor et al., 1996). For safety, many laboratories would discard any such heavily contaminated samples with respect to rapid prenatal diagnosis.
FISH

One of the disadvantages of FISH is that maternal and fetal XX cells per se are indistinguishable by FISH, rendering maternal cell contamination undetectable from female fetuses. This is not an uncommon reason for misdiagnosis (Table 5). However, maternal cell contamination is readily detectable with male fetuses, as a mixture of $X X$ and $X Y$ cells are then seen. (The same is found in cases of fetal true hermaphroditism but such cases are exceedingly rare.)

\section{QF-PCR}

In contrast to the situation with FISH, maternal cell contamination is readily detected by QF-PCR amplification of STRs. A characteristic pattern with extra alleles or skewed ratios between peaks for the target chromosomes is seen (Fig. 3g). Macroscopically bloodstained samples showing such results have in the past generally been considered unsuitable for PCR diagnosis. Nevertheless, accurate diagnosis may often be achieved by careful comparison with profiles from maternal blood samples.

\section{Constitutional fetal mosaicism remains a challenge by either method}

A related problem is the diagnosis of constitutional fetal mosaicism, the occurrence of different fetal cell lines containing different numbers of chromosomes.

\section{FISH}

The sensitivity of the FISH probes is not $100 \%$ (Table 1). Therefore, a relatively large number of cells (in the order of 25-50) have to be examined, and cutoff levels for proportions of apparently normal and apparently aneuploid nuclei set (Ward et al., 1993; Tepperberg et al., 2001). Low-grade mosaicism is likely to be missed. However, after karyotyping, FISH analysis of uncultured interphase amniocytes and chorionic villus cells may in fact aid diagnosis of any suspected constitutional mosaicism (Feldman et al., 2000; Siffroi et al., 2000). The FISH approach, which allows a higher number of interphase nuclei to be examined, may be of special advantage with respect to the problem of confined placental mosaicism in chorionic villus samples (Quilter et al., 2001).

\section{QF-PCR}

Mosaicism poses a challenge also when using QF-PCR for prenatal diagnosis. Mann et al. (2001) estimated that the QF-PCR assay is capable of identifying 
autosomal mosaicism, where the trisomy is present in more than $10 \%$ of in vitro cultured cells. Cirigliano et al. (1999) were able to detect six out of seven cases of Turner syndrome with 46,XX; 45,X mosaicism of variable degrees, as indicated by karyotyping. In the single case, which was not detected by QF-PCR, the abnormal cells $(45, X)$ were present in only $10 \%$ of cells of in vitro cultured amniocytes.

It may be added that prenatal diagnosis of constitutional mosacism is a very difficult problem altogether, not least because of the uncertain implications of mosaicism with respect to fetal and childhood development (Robinson et al., 2002). There is not a direct correspondence between the degree of mosaicism detected in different tissue samples, such as uncultured and cultured amniotic fluid and CVSs. Further research is urgently required to evaluate the clinical significance of different degrees of mosaicism, as detected in these different types of prenatal samples.

\section{A trend towards 'stand-alone' molecular tests}

Special attention has been paid to the potential for using FISH or QF-PCR for the diagnosis of common aneuploidies as 'stand-alone' tests. Opinions are divided. Bearing in mind that both amniocentesis and CVS are invasive procedures with a risk for induced abortion, it has been argued that follow-up by karyotyping should be performed to detect those chromosome abnormalities (in particular those associated with more or less severe physical and mental handicap) not identifiable by the current molecular tests. The proportion of such abnormalities, undetectable by current FISH and QFPCR aneuploidy assays is about $20-30 \%$, but varies considerably depending on the reasons for testing (Ward et al., 1993; Evans et al., 1999; Lewin et al., 2000; Pergament et al., 2000; Thein et al., 2000; Homer et al., 2003). For most women, when the indication for prenatal diagnosis is maternal age (in isolation or combined with maternal serum and ultrasonographic screening for fetal nuchal translucency), this risk is usually relatively low, in the order of 0.1-0.2\% (Grimshaw et al., 2003). In other words, in the low-risk group of women, the abnormality detection rate is around 99.8-99.9\%. In contrast, once a structural abnormality of the fetus has been diagnosed using ultrasonography, the risk may be substantially increased. The risk for a fetal chromosome abnormality is also substantially increased when either parent is a carrier of a chromosome rearrangement such as a translocation, inversion or insertion. Neither FISH nor QF-PCR aneuploidy assays are applicable. Either karyotyping or specific molecular testing (Chen et al., 2001 ) is mandatory.

Standard karyotyping also discovers structural chromosome rearrangements in balanced form, undetectable by current FISH and QF-PCR approaches. Carriers of structural chromosome rearrangements (such as trans- locations, inversions and insertions) are common in the general population and occur with an incidence of around one in 300. The incidence is not increased in amniotic fluid samples or CVSs, and the fetal carrier status may thus be a coincidental finding. Carrier status often runs in families. Detecting a structural chromosome rearrangement by prenatal diagnosis makes possible the unravelling of large families, where many carriers may be offered appropriate counselling regarding their reproductive risk (including reduced fertility and increased risks for abortions and stillbirths and for having a liveborn child with a chromosome abnormality). This potential is lost by application of the molecular tests as a 'stand-alone' approach.

\section{Summary and final remarks}

FISH and QF-PCR constitute molecular methods that allow rapid and simple yet reliable prenatal diagnosis of targeted fetal chromosome disorders. Currently, these molecular tests are used for the detection of the most common abnormalities, trisomy 21, 13 and 18 (giving rise to the Down, Patau and Edward syndromes, respectively) and sex chromosome abnormalities (associated with the XXY-Klinefelter, XYY, XXX and X-Turner syndromes). These methods are applied to fetal nondividing cells and DNA obtained using the invasive procedures amniocentesis and CVS. The methods are used mainly as a preamble to traditional karyotyping, performed after in vitro cell culture, using an aliquot of the same sample. However, a debate continues about the potential advantage for introducing these as 'stand-alone' tests for routine prenatal chromosome diagnosis in lowrisk pregnancies (Ogilvie, 2003). This would be a highly cost-effective policy in relation to the current practice of both molecular and traditional testing (Grimshaw et al., 2003).

It is hoped that, in not too distant a future, the same technology may be applied for 'non-invasive' prenatal diagnosis on fetal cells or DNA retrieved from maternal blood samples, leading to a reduced requirement for invasive procedures that carry a risk for associated fetal loss. In the interim, the introduction of these targeted molecular methods per se may focus attention on the urgent need for appropriate information to be given to pregnant women (and their partners) regarding what fetal conditions may be looked for; and following discussions on the implications of the various disorders for child development, informed parental choices may be improved over and above the current situation (Marteau and Dormandy, 2001).

The authors are grateful to M. Tankimanova for the assistance with Figs 1 and 2a; H. Olsson, Cybergene Ltd, Stockholm for the electrophoretograms in Fig. 3a,b; and G. Voglino for the electrophoretograms in Fig. $3 \mathrm{c}-\mathrm{f}$ (presented at the QF-PCR II training course 2002 in Torino, Italy). 
Table 2. Small (short) tandem repeats (STRs) and primers commonly used for the detection of trisomies 21, 18, 13 and the sex chromosome abnormalities

\begin{tabular}{|c|c|c|c|c|c|}
\hline Marker name & Heterozygosity (\%) & $\begin{array}{l}\text { Size of PCR } \\
\text { product (bp) }\end{array}$ & Primer sequence & $\begin{array}{l}\text { Chromosome } \\
\text { location }\end{array}$ & Source and reference \\
\hline D21S11 & 90.0 & $225-280$ & $\begin{array}{l}\text { TATGTGAGTCAATTCCCCAAGTGA (F) } \\
\text { GTTGTATTAGTCAATGTTCTCCAG (R) }\end{array}$ & $21 q 21$ & GDB, Pertl et al., 1996 \\
\hline \multirow[t]{2}{*}{ D21S1411 } & 93.0 & $\geqslant 239$ & $\begin{array}{l}\text { ATGATGAATGCATAGATGGATG (F) } \\
\text { AATGTGTGTCCTTCCAGGC (R) }\end{array}$ & $21 q 22.3$ & GDB, Pertl et al., 1996 \\
\hline & & $256-340$ & $\begin{array}{l}\text { GTAGATACATACATATGATGAATGC (F) } \\
\text { TATTAATGTGTGTCCTTCCAGGC }(\mathrm{R})\end{array}$ & & *Mann et al., 2001 \\
\hline D21S1412 & 85.4 & $384-414$ & $\begin{array}{l}\text { CGGAGGTTGCAGTGAGTTG (F) } \\
\text { GGGAAGGCTATGGAGGAGA (R) }\end{array}$ & $21 q 22.2$ & GDB, Pertl et al., 1997 \\
\hline D21S1413 & 87.5 & $\geqslant 180$ & $\begin{array}{l}\text { TTGCAGGGAAACCACAGTT (F) } \\
\text { TCCTTGGAATAAATTCCCGG (R) }\end{array}$ & 21 & GDB, Schmidt et al., 2000 \\
\hline \multirow[t]{2}{*}{$\begin{array}{l}\text { D21S1414 (amplifies } \\
\text { the same region as } \\
\text { D21S11 but produces a } \\
\text { 122bp larger amplicon) }\end{array}$} & 88.0 & $\geqslant 291$ & $\begin{array}{l}\text { GGCACCCAGTAAAAAATTACT (F) } \\
\text { CTGTCTGTCTGTCTGTCTATC (R) }\end{array}$ & $21 q 21$ & GDB \\
\hline & & $330-380$ & $\begin{array}{l}\text { AAATTAGTGTCTGGCACCCAGTA (F) } \\
\text { CAATTCCCCAAGTGAATTGCCTTC (R) }\end{array}$ & $21 q 21$ & *Pertl et al., 1996 \\
\hline D21S1435 & 79.0 & $163-187$ & $\begin{array}{l}\text { CCСТCTCAATTGTTTGTCTACC (F) } \\
\text { GCAAGAGATTTCAGTGCCAT (R) }\end{array}$ & $21 q 21$ & GDB, Cirigliano et al., 2001 \\
\hline D21S1270 & 86.0 & $285-340$ & $\begin{array}{l}\text { CTATCCCACTGTATTATTCAGGGC (F) } \\
\text { TGAGTCTCCAGGTTGCAGGTGACA (R) }\end{array}$ & $21 q 21-q 22.1$ & Mann et al., 2001 \\
\hline $\mathrm{D} 21 \mathrm{~S} 226$ & 59.0 & $440-470$ & $\begin{array}{l}\text { GCAAATTTGTGGATGGGATTAACAG (F) } \\
\text { AAGCTAAATGTCTGTAGTTATTCT (R) }\end{array}$ & $21 q 22.1$ & Mann et al., 2001 \\
\hline D21S1246 & 75.0 & $\geqslant 400$ & $\begin{array}{l}\text { GATAAAGTAGACAGGTAAACA (F) } \\
\text { GGATTATAATTCAAGATGAGAT (R) }\end{array}$ & $21 q 22.2$ & GDB \\
\hline \multirow[t]{2}{*}{ IFNAR (D21S2039) } & 83.0 & $231-251$ & $\begin{array}{l}\text { TTACGTTCTTCATTTGATCTTAGCC (F) } \\
\text { CCAGGCATGATGGCACAC }(\mathrm{R})\end{array}$ & $21 q 22.1$ & GDB, Verma et al., 1998 \\
\hline & & $450-500$ & $\begin{array}{l}\text { GTTCTTCATTTGATCTTAGCCATC (F) } \\
\text { GTGAGATAACTGGCAAGAAGATAA (R) }\end{array}$ & $21 q 22.1$ & *Mann et al., 2001 \\
\hline D13S631 & 83.0 & $189-223$ & $\begin{array}{l}\text { GGCAACAAGAGCAAAACTCT (F) } \\
\text { TAGCCCTCACCATGATTGG (R) }\end{array}$ & $13 q 31-32$ & GDB, Pertl et al., 1997 \\
\hline \multirow[t]{2}{*}{ D13S634 } & 81.2 & $\geqslant 375$ & $\begin{array}{l}\text { TCCAGATAGGCAGATTCAAT }(\mathrm{F}) \\
\text { CCTTCTTCTTCCCATTGATA }(\mathrm{R})\end{array}$ & $13 q 14.3$ & GDB, Pertl et al., 1997 \\
\hline & & $385-440$ & $\begin{array}{l}\text { GGCAGATTCAATAGGATAAATAGA (F) } \\
\text { GTAACCCCTCAGGTTCTCAAGTCT (R) }\end{array}$ & $13 q 14.3$ & *Mann et al., 2001 \\
\hline D13S258 & 83.3 & $230-267$ & $\begin{array}{l}\text { ACCTGCCAAATTTTACCAGG (F) } \\
\text { GACAGAGAGAGGGAATAAACC (R) }\end{array}$ & $13 q 21.2-q 31$ & GDB, Pertl et al., 1999 \\
\hline D13S303 & 90.9 & $338-354$ & $\begin{array}{l}\text { ACATCGCTCCTTACCCCATC (F) } \\
\text { TGTACCCATTAACCATCCCCA (R) }\end{array}$ & $13 q 22-q 31$ & GDB, Schmidt et al., 2000 \\
\hline D13S256 & 90.0 & $\geqslant 154$ & $\begin{array}{l}\text { CCTGGGCAACAAGAGCAAA (F) } \\
\text { AGCAGAGAGACATAATTGTG (R) }\end{array}$ & $13 q 14.1-q 22$ & GDB, Schmidt et al., 2000 \\
\hline D13S628 & 68.8 & $\geqslant 247$ & $\begin{array}{l}\text { ACGCCACTTTTCTAAATGCC (F) } \\
\text { GGAGTAACAAATAGCAAGGCT (R) }\end{array}$ & $13 q 31-q 32$ & GDB \\
\hline
\end{tabular}


Table 2. (Continued)

\begin{tabular}{|c|c|c|c|c|c|}
\hline Marker name & Heterozygosity (\%) & $\begin{array}{l}\text { Size of PCR } \\
\text { product (bp) }\end{array}$ & Primer sequence & $\begin{array}{l}\text { Chromosome } \\
\text { location }\end{array}$ & Source and reference \\
\hline & & $425-470$ & $\begin{array}{l}\text { TAACATTCATTGTCCCTTACAGAT (F) } \\
\text { GCAAGGCTATCTAACGATAATTCA (R) }\end{array}$ & $13 q 31-q 32$ & *Mann et al., 2001 \\
\hline \multirow[t]{2}{*}{ D13S742 } & 75.0 & $\geqslant 364$ & $\begin{array}{l}\text { TCCAGCCTGGTCAACACAG }(\mathrm{F}) \\
\text { TCCAGACTTCCCAATTCAGG }(\mathrm{R})\end{array}$ & $13 q 11-q 21.1$ & GDB \\
\hline & & $235-315$ & $\begin{array}{l}\text { ATAACTGGGCTAGGAATGGAAATA (F) } \\
\text { GACTTCCCAATTCAGGAGGACT (R) }\end{array}$ & $13 q 11-q 21.1$ & *Mann et al., 2001 \\
\hline D13S305 & 75.0 & $430-465$ & $\begin{array}{l}\text { GCCTGTTTGAGGACCTGTCGTTA (F) } \\
\text { TGGTTATAGAGCAGTTAAGGCAC (R) }\end{array}$ & $13 q 12.1-q 14.1$ & GDB, Mann et al., 2001 \\
\hline MBP & $\begin{array}{l}\text { LOCUS A:80 } \\
\text { LOCUS B:79 }\end{array}$ & $\begin{array}{l}\text { A: } 122-124 \\
\text { B:208-232 }\end{array}$ & $\begin{array}{l}\text { GGACCTCTGGAATTACAATC (F) } \\
\text { ATTTAACCTACCTGTTCATCC (R) }\end{array}$ & $18 \mathrm{q} 23-$ ter & GDB, Pertl et al., 1996 \\
\hline \multirow[t]{2}{*}{ D18S51 } & 88.5 & $271-331$ & $\begin{array}{l}\text { GAGCCATGTTCATGCCACTG (F) } \\
\text { CAAACCCGACTACCAGCAAC (R) }\end{array}$ & $18 q 21.33$ & GDB \\
\hline & 80.2 & $279-323$ & $\begin{array}{l}\text { CCAACCCGACTACCAGCAAC (F) } \\
\text { GAGCCATGTTCATGCCACTG }(\mathrm{R})\end{array}$ & $18 q 21.33$ & *Schmidt et al., 2000 \\
\hline D18S499 & 71.0 & $150-178$ & $\begin{array}{l}\text { CTGCACAACATAGTGAGACCTG }(\mathrm{F}) \\
\text { AGATTACCCAGAAATGAGATCAGC }(\mathrm{R})\end{array}$ & $18 q 21.32-q 21.33$ & GDB, Schmidt et al., 2000 \\
\hline \multirow[t]{2}{*}{ D18S380 } & 66.7 & $\geqslant 151$ & $\begin{array}{l}\text { CACTGCATTCTGGGCAAC (F) } \\
\text { AGGCTCTTGCTCCTGGAAT (R) }\end{array}$ & $18 q 22.3-q 23$ & GDB \\
\hline & & $160-200$ & $\begin{array}{l}\text { GCATTCTGGGCAACAAGGTGAAAC (F) } \\
\text { GAGATAACCCAGGCAAGAACAGGA (R) }\end{array}$ & $18 q 22.3-q 23$ & *Mann et al., 2001 \\
\hline \multirow[t]{2}{*}{ D18S391 } & 75.0 & $\geqslant 182$ & $\begin{array}{l}\text { CTGGTTTTCGTCTTGAGAAG (F) } \\
\text { CACTATTCCCATCTGAGTCA (R) }\end{array}$ & 18pter-18p11.22 & GDB \\
\hline & & $140-180$ & $\begin{array}{l}\text { GGACTTACCACAGGCAATGTGACT (F) } \\
\text { TAGACTTCACTATTCCCATCTGAG (R) }\end{array}$ & 18pter-18p11.22 & *Mann et al., 2001 \\
\hline \multirow[t]{2}{*}{ D18S535 } & 74.6 & $126-156$ & $\begin{array}{l}\text { TCATGTGACAAAAGCCACAC (F) } \\
\text { AGACAGAAATATAGATGAGAATGCA (R) }\end{array}$ & $18 q 12.2$ & GDB, Pertl et al., 1999 \\
\hline & 92.0 & $455-500$ & $\begin{array}{l}\text { CAGCAAACTTCATGTGACAAAAGC (F) } \\
\text { CAATGGTAACCTACTATTTACGTC (R) }\end{array}$ & $18 q 12.2-q 12.3$ & *Mann et al., 2001 \\
\hline D18S1002 & 81.2 & $286-318$ & $\begin{array}{l}\text { CAAAGAGTGAATGCTGTACAAACAGC (F) } \\
\text { CAAGATGTGAGTGTGCTTTTCAGGAG }(\mathrm{R})\end{array}$ & $18 q 11$ & GDB, Schmidt et al., 2000 \\
\hline \multirow[t]{2}{*}{ D18S386 } & 92.3 & $330-387$ & $\begin{array}{l}\text { TCAGGAGAATCACTTGGAAC (F) } \\
\text { TCCATGAAGTAGCTAAGCAG (R) }\end{array}$ & $18 q 22.1-q 22.2$ & GDB, Pertl et al., 1999 \\
\hline & 87.5 & $330-400$ & $\begin{array}{l}\text { TGAGTCAGGAGAATCACTTGGAAC (F) } \\
\text { CTCTTCCATGAAGTAGCTAAGCAG (R) }\end{array}$ & $18 q 22.1-q 22.2$ & *Mann et al., 2001 \\
\hline D18S858 & 82.0 & $193-211$ & $\begin{array}{l}\text { AGCTGGAGAGGGATAGCATT (F) } \\
\text { TGCATTGCATGAAAGTAGGA (R) }\end{array}$ & 18 & $\begin{array}{l}\text { GDB, G. Voglino personal } \\
\text { communication }\end{array}$ \\
\hline XHPRT & 73.3 & $260-302$ & $\begin{array}{l}\text { ATGCCACAGATAATACACATCCCC (F) } \\
\text { CTCTCCAGAATAGTTAGATGTAGGTAT (R) }\end{array}$ & $\mathrm{Xq} 26.1$ & Pertl et al., 1997 \\
\hline DXS8377 & 95.0 & $203-245$ & $\begin{array}{l}\text { CACTTCATGGCTTACCACAG (F) } \\
\text { GACCTTTGGAAAGCTAGTGT (R) }\end{array}$ & $\mathrm{Xq} 26$ & GDB, Schmidt et al., 2000 \\
\hline
\end{tabular}




\begin{tabular}{|c|c|c|c|c|c|}
\hline DXS6803 & 86.7 & $106-125$ & $\begin{array}{l}\text { GAAATGTGCTTTGACAGGAA }(\mathrm{F}) \\
\text { CAAAAAGGGACATATGCTACTT }(\mathrm{R})\end{array}$ & Xpter-qter & GDB, Cirigliano et al., 2001 \\
\hline DXS6809 & 86.7 & $242-274$ & $\begin{array}{l}\text { TGAACCTTCCTAGCTCAGGA }(\mathrm{F}) \\
\text { TCTGGAGAATCCAATTTTGC }(\mathrm{R})\end{array}$ & Xpter-qter & GDB, Cirigliano et al., 2001 \\
\hline $\mathrm{X} 22$ & 85.2 & 189-242 & $\begin{array}{l}\text { TAATGAGAGTTGGAAAGAAA }(\mathrm{F}) \\
\text { CCCATTGTTGCTACTTGAGA }(\mathrm{R})\end{array}$ & Xq28 (PAR2) & Cirigliano et al., 1999 \\
\hline AMXY & & $\begin{array}{l}X-432 \\
Y-250\end{array}$ & $\begin{array}{l}\text { CTGATGGTTGGCCTCAAGCCT (F) } \\
\text { ATGAGGAAACCAGGGTTCCA (R) }\end{array}$ & $\mathrm{X}$ and $\mathrm{Y}$ & Pertl et al., 1996 \\
\hline & & $\begin{array}{l}X-106 \\
Y 112\end{array}$ & $\begin{array}{l}\text { СССТGGGCTCTGTAAAGAATAGT (F) } \\
\text { ATCAGAGCTTAAACTGGGAAGCTG }(\mathrm{R})\end{array}$ & $\begin{array}{l}\text { Xp22.1-22.31 } \\
\text { Yp26.1 }\end{array}$ & Cirigliano et al., 1999 \\
\hline SBMA & 90.0 & $142-178$ & $\begin{array}{l}\text { TCC GCG AAG TGA AGA AC }(\mathrm{F}) \\
\text { CTT GGG GAG AAC CAT CCT CA (R) }\end{array}$ & $\mathrm{Xq} 11.2-\mathrm{q} 12$ & Schmidt et al., 2000 \\
\hline DXS981 & 86.0 & $230-260$ & $\begin{array}{l}\text { CTCCTTGTGGCCTTCCTTAAATG (F) } \\
\text { TTCTCTCCACTTTTCAGAGTCA }(R)\end{array}$ & $\mathrm{Xq11.2-q13.1}$ & GDB, Donaghue et al., 2003 \\
\hline DXS6854 & 73.0 & $90-125$ & $\begin{array}{l}\text { AGCACTTCTCCTACAACCCTC (F) } \\
\text { CAGCCTGGGCAGTAGAGACT (R) }\end{array}$ & $\mathrm{Xq} 26$ & GDB, Donaghue et al., 2003 \\
\hline P39 & 87.0 & 140-166 & $\begin{array}{l}\text { AGCACATGGTATAATGAACCTCCACG }(\mathrm{F}) \\
\text { CAGTGTGAGTAGCATGCTAGCATTTG }(\mathrm{R})\end{array}$ & Xq28 & Donaghue et al., 2003 \\
\hline DXS996 & 82.0 & $130-168$ & $\begin{array}{l}\text { AAATTCTTGCTTAGGCCACTCTAGG }(\mathrm{F}) \\
\text { AACGTTGTTCTGGATCGTATGCTA }(\mathrm{R})\end{array}$ & Xp22.3 & GDB, Donaghue et al., 2003 \\
\hline DXS337 & 83.0 & 163-193 & $\begin{array}{l}\text { TGCATCATTCAGCTTTCAGG }(\mathrm{F}) \\
\text { GTGACAGAGTGAGACCCTGTC (R) }\end{array}$ & Xp11.3-p11.23 & GDB, Pertl et al., 1999 \\
\hline DXS1283 & 95.0 & $203-245$ & $\begin{array}{l}\text { AGTTTAGGAGATTATCAAGCTGG (F) } \\
\text { GTTCCCATAATAGATGTATCCAG }(\mathrm{R})\end{array}$ & & Schmidt et al., 2000 \\
\hline
\end{tabular}

*These primer sequences have been modified since their first use.

GDB: Genome database.

The references in this table are examples in which these particular markers have been used successfully in quantitative fluorescence polymerase chain reaction (QF-PCR) for the prenatal detection of chromosomal aneuploidies and do not refer to the groups who had first published the sequences. 
Table 3. Examples of recent studies of prenatal diagnosis using quantitative fluorescence polymerase chain reaction (QF-PCR) with markers specific for chromosomes $21,18,13, \mathrm{X}$ and $\mathrm{Y}$

\begin{tabular}{|c|c|c|c|c|c|c|c|}
\hline $\begin{array}{l}\text { Number of cases } \\
\text { analysed by } \\
\text { QF-PCR/Total }\end{array}$ & $\begin{array}{l}\text { Chromosomes } \\
\text { tested }\end{array}$ & $\begin{array}{c}\text { Abnormalities } \\
\text { detected/total } \\
\text { analysed by PCR }(\%)\end{array}$ & $\begin{array}{c}\text { Abnormalities } \\
\text { not detected/total } \\
\text { analysed by PCR }(\%)\end{array}$ & $\begin{array}{l}\text { Number of STR } \\
\text { markers used }\end{array}$ & $\begin{array}{c}\text { Informativeness } \\
(\%)\end{array}$ & $\begin{array}{l}\text { Heavily blood } \\
\text { stained samples (\%) }\end{array}$ & Reference \\
\hline $\begin{array}{l}2083 / 2167 \\
\text { Total } 2083\end{array}$ & 21 & $\begin{array}{l}32(1.5) \\
32(\mathbf{1 . 5})\end{array}$ & $\begin{array}{c}0 \\
\mathbf{0}(\mathbf{0})\end{array}$ & 3 & 99.6 & 1.3 & Verma et al., 1998 \\
\hline $662 / 662$ & $\begin{array}{l}21 \\
18 \\
13 \\
X Y\end{array}$ & $\begin{array}{c}5(0.8) \\
4(0.6) \\
0(0.0) \\
45, X-4(0.6) \\
47, X X Y-1(0.2)\end{array}$ & $\begin{array}{c}0 \\
1(0.02) \\
0 \\
0\end{array}$ & $\begin{array}{l}3 \\
3 \\
3 \\
3\end{array}$ & $\begin{array}{l}98.3 \\
97.3 \\
94.6\end{array}$ & 1.0 & Schmidt et al., 2000 \\
\hline Total 662 & & $14(0.3)$ & $1(0.02)$ & & & & \\
\hline $5000 / 5097$ & $\begin{array}{l}21 \\
18 \\
13 \\
X Y\end{array}$ & $\begin{array}{c}57(1.1) \\
17(0.3) \\
8(0.2) \\
16 \text { in total }(0.3)\end{array}$ & $\begin{array}{l}0 \\
0 \\
0 \\
4\end{array}$ & $\begin{array}{c}6 \\
6 \\
6 \\
X-5 \\
Y-2\end{array}$ & 98.0 overall & 2.0 & Levett et al., 2001 \\
\hline Total 5000 & & $98(1.9)$ & $4(0.1)$ & & & & \\
\hline Total 1314 & $\begin{array}{l}21 \\
18 \\
13\end{array}$ & $\begin{array}{l}55(4.2) \\
23(1.8) \\
10((0.8) \\
\mathbf{8 8}(\mathbf{6 . 7 )}\end{array}$ & $\begin{array}{c}0 \\
0 \\
0 \\
\mathbf{0}(\mathbf{0})\end{array}$ & $\begin{array}{l}4 \\
4 \\
4\end{array}$ & 99.5 overall & 2.0 & Mann et al., 2001 \\
\hline Total 5090 & $\begin{array}{l}21 \\
18 \\
13\end{array}$ & $\begin{array}{c}189(3.7) \\
75(1.5) \\
32(0.6) \\
\mathbf{2 9 6}(\mathbf{5 . 8})\end{array}$ & $\begin{array}{c}0 \\
0 \\
0 \\
\mathbf{0}(\mathbf{0})\end{array}$ & $\begin{array}{l}4\left(2^{*}\right) \\
4\left(2^{*}\right) \\
4\left(2^{*}\right)\end{array}$ & 99.5 overall & 1.5 & $\begin{array}{l}\text { K. Mann, personal } \\
\text { communication }\end{array}$ \\
\hline $3478 / 3478$ & $\begin{array}{l}21 \\
18 \\
13 \\
X Y\end{array}$ & $\begin{array}{c}58(1.7) \\
28(0.8) \\
7(0.2) \\
14 \text { in total }(0.4)\end{array}$ & $\begin{array}{l}0 \\
0 \\
0 \\
0\end{array}$ & & $\begin{array}{l}98.8 \\
98.5\end{array}$ & 1.2 & $\begin{array}{l}\text { V. Cirigliano, } \\
\text { personal } \\
\text { communication, } \\
\text { ISPD conference, } \\
2002\end{array}$ \\
\hline Total & & $107(3.1)$ & $\mathbf{0}(\mathbf{0})$ & & & & \\
\hline 1653/1653 & $\begin{array}{l}21 \\
18 \\
13 \\
X Y\end{array}$ & $\begin{array}{c}110(6.6) \\
40(2.4) \\
15(0.9) \\
45, X-18(1.1) \\
47, X X Y-4(0.2) \\
47, X Y Y-3(0.2)\end{array}$ & $\begin{array}{l}0 \\
0 \\
0 \\
0 \\
0 \\
0\end{array}$ & & 98.9 & Not recorded & Voglino et al., 2002 \\
\hline Total 1653 & & $187(11.3)$ & $\mathbf{0}(\mathbf{0})$ & & & & \\
\hline Grand total 17966 & & 822 (4.6) & $5(0.03)$ & & & & \\
\hline
\end{tabular}

Note the relatively low proportion of abnormalities missed in these studies, in total five of $17966(0.03 \%)$. In addition, note that the informativeness (proportion of cases showing heterozygosity for the markers concerned) is usually in the order of 98-99\%. Triploidy and cases of mosaicism are not included.

If all the primary markers are uninformative, additional ones may be used to increase the informativeness. Number of additional markers used is indicated by an *

STR: small (short) tandem repeat. 
Table 4. Examples of large or recent prenatal diagnosis studies using fluorescence in situ hybridization (FISH) probes specific for chromosomes $21,18,13, \mathrm{X}$ and $\mathrm{Y}$

\begin{tabular}{|c|c|c|c|c|c|c|c|}
\hline $\begin{array}{l}\text { Number of } \\
\text { cases analysed } \\
\text { by FISH/total }\end{array}$ & $\begin{array}{c}\text { Chromosomes } \\
\text { tested }\end{array}$ & $\begin{array}{c}\text { Abnormalities } \\
\text { detected/total } \\
\text { analysed by FISH (\%) }\end{array}$ & $\begin{array}{c}\text { Abnormalities } \\
\text { not detected/total } \\
\text { analysed by FISH (\%) }\end{array}$ & Probes used & Informativeness (\%) & $\begin{array}{l}\text { Blood stained } \\
\text { samples }(\%)\end{array}$ & Reference \\
\hline $4059 / 4500$ & $\begin{array}{l}21 \\
18 \\
13 \\
X Y\end{array}$ & $\begin{array}{c}38(0.9) \\
30(0.7) \\
12(0.3) \\
45, X-12(0.3) \\
47, X X Y-4(0.1) \\
47, X X X-4(0.1)\end{array}$ & $\begin{array}{c}5(0.1) \text { false neg } \\
1(0.02) \text { false neg } \\
1(0.02) \text { false neg } \\
1(0.02) \text { false pos }\end{array}$ & Cosmids & 99.2 & 3.8 & Ward et al., 1993 \\
\hline Total 4059 & & $100(2.5)$ & $8(0.2)$ & & & & \\
\hline Total 2523 & $\begin{array}{l}21 \\
18 \\
13 \\
X Y\end{array}$ & $\begin{array}{c}48(0.02) \\
14(0.01) \\
10(0.003) \\
8 \text { in total }(0.003) \\
\mathbf{8 0}(\mathbf{0 . 0 3})\end{array}$ & $\begin{array}{l}0 \\
0 \\
0 \\
0 \\
\mathbf{0}\end{array}$ & Cosmids & 93.0 & 0 & Bryndorf et al., 1996 \\
\hline $\begin{array}{l}2079 / 2154 \\
\text { Total } 2079\end{array}$ & 21 & $\begin{array}{l}48(2.3) \\
48(2.3)\end{array}$ & $\begin{array}{l}0 \\
\mathbf{0}\end{array}$ & Yac 831B9 & 99.7 & 2.9 & Morris et al., 1999 \\
\hline $2336 / 2336$ & $\begin{array}{l}21 \\
18 \\
13 \\
X Y\end{array}$ & $24(0.9)$ in total & 0 & Aneuvysion, Vysis & 100.0 & Not recorded & $\begin{array}{l}\text { Pergament et al., } \\
2000\end{array}$ \\
\hline Total 2336 & & $24(0.9)$ & $\mathbf{0}$ & & & & \\
\hline Total 3202 & $\begin{array}{l}21 \\
18 \\
13 \\
X Y\end{array}$ & $\begin{array}{c}45(1.4) \\
25(0.7) \\
5(0.2) \\
45, X-4(0.1) \\
47, X X Y-4(0.1) \\
\mathbf{8 3}(\mathbf{2 . 6 )}\end{array}$ & $\mathbf{0}$ & Aneuvysion, Vysis & 99.9 & Not recorded & $\begin{array}{l}\text { Thilaganathan et al., } \\
\quad 2000\end{array}$ \\
\hline Total 301 & $\begin{array}{l}21 \\
13 \\
18 \\
X Y\end{array}$ & $\begin{array}{c}14(4.7) \\
3(0.9) \\
10(3.3) \\
45, X-4(1.3) \\
\mathbf{3 1}(\mathbf{9 . 9 )}\end{array}$ & $\begin{array}{l}0 \\
0 \\
0 \\
0 \\
\mathbf{0}\end{array}$ & $\begin{array}{l}\text { Oncor and Aneuvysion, } \\
\text { Vysis }\end{array}$ & 100.0 & Not recorded & Feldman et al., 2000 \\
\hline 309/309 & $\begin{array}{l}21 \\
18 \\
13 \\
X Y\end{array}$ & $\begin{array}{c}21(6.8) \\
12(3.8) \\
3(1.0) \\
45, X-4(1.3) \\
47, X X Y-2(0.6) \\
\mathbf{4 2}(\mathbf{1 3 . 6 )}\end{array}$ & $\begin{array}{c}1(0.3) \text { false neg } \\
1(0.3) \text { false neg } \\
2(0.6) \text { false neg } \\
0 \\
0 \\
4 \mathbf{( 1 . 3 )}\end{array}$ & $\begin{array}{l}\text { Oncor and Aneuvysion, } \\
\text { Vysis }\end{array}$ & $\begin{array}{c}95.1 \\
(7 / 15 \text { late } 25-40 \\
\text { week amnios })\end{array}$ & Not recorded & $\begin{array}{l}\text { Cheong Leung et al., } \\
2001\end{array}$ \\
\hline
\end{tabular}


Table 4. (Continued)

\begin{tabular}{|c|c|c|c|c|c|c|c|}
\hline $\begin{array}{l}\text { Number of } \\
\text { cases analysed } \\
\text { by FISH/total }\end{array}$ & $\begin{array}{l}\text { Chromosomes } \\
\text { tested }\end{array}$ & $\begin{array}{c}\text { Abnormalities } \\
\text { detected/total } \\
\text { analysed by FISH (\%) }\end{array}$ & $\begin{array}{c}\text { Abnormalities } \\
\text { not detected/total } \\
\text { analysed by FISH }(\%)\end{array}$ & Probes used & Informativeness (\%) & $\begin{array}{l}\text { Blood stained } \\
\text { samples (\%) }\end{array}$ & Reference \\
\hline Total 5197 & $\begin{array}{l}21 \\
18 \\
13 \\
X Y\end{array}$ & $\begin{array}{c}183(3.5) \\
195(3.8) \\
73(1.4) \\
45, X-64(1.2) \\
\mathbf{5 1 5}(\mathbf{9 . 9 )}\end{array}$ & $\begin{array}{c}0 \\
1(0.02) \\
1(0.02) \\
0 \\
\mathbf{0}\end{array}$ & Aneuvysion, Vysis & 97.2 & 0.2 & $\begin{array}{l}\text { Tepperberg et al., } \\
2001\end{array}$ \\
\hline $911 / 11123$ & $\begin{array}{l}21 \\
18 \\
13 \\
X Y\end{array}$ & $\begin{array}{c}35(3.8) \\
21(2.3) \\
5(0.5) \\
45, X-6(0.6) \\
47, X X Y-1(0.1) \\
\mathbf{6 8}(7.5)\end{array}$ & $\begin{array}{c}3 \text { false neg } \\
2 \text { false neg } \\
0 \\
0 \\
0 \\
\mathbf{5}(\mathbf{0 . 5 )}\end{array}$ & $\begin{array}{l}\text { Oncor and Aneuvysion, } \\
\text { Vysis }\end{array}$ & 97.0 & Not recorded & $\begin{array}{l}\text { Weremowicz et al. } \\
2001\end{array}$ \\
\hline $\begin{array}{l}\text { 5049/5049 for } \\
\text { chromosome } \\
\text { 21, not recorded } \\
\text { for } 18,13, \\
X \text { and } Y\end{array}$ & $\begin{array}{l}21 \\
18 \\
13 \\
X Y\end{array}$ & $\begin{array}{c}70(1.4) \\
15(0.3) \\
5(0.1) \\
45, X-12(0.2) \\
47, X X Y-1(0.02) \\
47, X X X-1(0.02)\end{array}$ & $\begin{array}{l}0 \\
0 \\
0 \\
0\end{array}$ & Aneuvysion, Vysis & 99.7 & 1.3 & Witters et al., 2002 \\
\hline Total 5049 & & $104(2.1)$ & $\mathbf{0}$ & & & & \\
\hline Grand total 20453 & & $967(4.7)$ & $17(0.08)$ & & & & \\
\hline
\end{tabular}

Note the relatively low proportion of abnormalities missed in studies during the last three years, in total nine of 14187 (0.06\%). In addition, note that the informativeness (proportion of cases where a diagnosis could be obtained) is usually over $99 \%$. Triploidy and cases of mosaicism are not included. 
Table 5. Type and reason for misdiagnosis by fluorescence in situ hybridization (FISH) using the different types of probes

\begin{tabular}{|c|c|c|c|c|c|c|}
\hline Probe used & Source of probe & FISH signals & $\begin{array}{l}\text { Case } \\
\text { karyotype }\end{array}$ & Potential misdiagnosis & Explanation given & Reference \\
\hline $13 / 21$ & Not specified & $+13 / 21$ & $46, X X$ or $X Y$ & $\begin{array}{l}\text { False positive trisomy } \\
21 / \text { trisomy } 13 \text { or false } \\
\text { negative normal } \\
\text { if trisomy } 21 / \text { trisomy } 13\end{array}$ & $\begin{array}{l}\text { Probe hybridized to } \\
\text { chromosome } 22\end{array}$ & Strovel et al., 1992 \\
\hline $\begin{array}{l}\text { D13Z1/ } \\
\text { D21Z1 }\end{array}$ & Oncor & $+13 / 21$ & $46, X X$ & $\begin{array}{l}\text { False positive trisomy } \\
21 / \text { trisomy } 13 \text { or false } \\
\text { negative normal if } \\
\text { trisomy } 21 / \text { trisomy } 13\end{array}$ & $\begin{array}{l}\text { Probe hybridized to } \\
\text { chromosome } 22\end{array}$ & Verlinsky et al., 1995 \\
\hline L1.26 & Not specified & $+13 / 21$ & $46, X Y$ & $\begin{array}{l}\text { False positive trisomy } \\
21 / \text { trisomy } 13 \text { or false } \\
\text { negative normal } \\
\text { if trisomy } 21 / \text { trisomy } 13\end{array}$ & $\begin{array}{l}\text { Probe hybridized to } \\
\text { chromosome } 22\end{array}$ & Tardy and Toth, 1997 \\
\hline L1.26 & Devilee, 1986 & $\begin{array}{l}\text { Two extra } 13 / 21 \\
\text { signals }\end{array}$ & $47,+21$ & $\begin{array}{l}\text { False positive tetrasomy } \\
21 / \text { tetrasomy } 13\end{array}$ & $\begin{array}{l}\text { Probe hybridized to } \\
\text { chromosome } 14\end{array}$ & Lapidot-Lifson et al., 1996 \\
\hline $\begin{array}{l}\text { D13Z1/ } \\
\text { D21Z1 }\end{array}$ & Not specified & $-13 / 21$ & $46, X X$ & $\begin{array}{l}\text { False positive monosomy } \\
21 / 13 \text { or false negative } \\
\text { normal if trisomy } 21 / 13\end{array}$ & $\begin{array}{l}\text { Pericentromeric deletion of } \\
\text { chromosome } 21, \\
\text { maternally inherited }\end{array}$ & Mizunoe and Young, 1992 \\
\hline $\begin{array}{r}13 / 21 \text { PCR } \\
\text { fragment }\end{array}$ & Homebrew & $-13 / 21$ & $46, X X$ or $X Y$ & $\begin{array}{c}\text { False positive monosomy } \\
21 / 13 \text { or false negative } \\
\text { normal if trisomy } 21 / 13\end{array}$ & $\begin{array}{l}\text { Weak chromosome } 21 \\
\text { signal due to } \\
\text { centromeric deletion }\end{array}$ & Weier and Gray, 1992 \\
\hline Not specified & Pinkel, 1986 & $-13 / 21$ & $46, X Y$ & $\begin{array}{c}\text { False positive monosomy } \\
21 / 13 \text { or false negative } \\
\text { normal if trisomy } 21 / 13\end{array}$ & $\begin{array}{l}\text { Heteromorphism in } \\
\text { centromeric area of } \\
\text { chromosome } 21\end{array}$ & Seres-Santamaria et al., 1993 \\
\hline $\begin{array}{l}\text { D13Z1/ } \\
\text { D21Z1 }\end{array}$ & Devilee, 1986 & $-13 / 21$ & $\begin{array}{l}47,+21 \text { two } \\
\text { cases }\end{array}$ & $\begin{array}{l}\text { False negative normal or } \\
\text { false positive monosomy } \\
21 / 13 \text { if normal }\end{array}$ & $\begin{array}{l}\text { Deletion in centromeric } \\
\text { sequences, paternally } \\
\text { inherited }\end{array}$ & Verma and Luke, 1992 \\
\hline $\begin{array}{l}\text { D13Z1/ } \\
\text { D21Z1 }\end{array}$ & Oncor & $-13 / 21$ & $\begin{array}{l}47,+21 \text { two } \\
\text { cases }\end{array}$ & $\begin{array}{l}\text { False negative normal } \\
\text { or false positive } \\
\text { monosomy } 21 / 13 \\
\text { if normal }\end{array}$ & $\begin{array}{l}\text { Variations in signal } \\
\text { intensity not allowing } \\
\text { differentiation between } \\
\text { normal and abnormal } \\
\text { signals }\end{array}$ & Cacheux et al., 1994 \\
\hline $\begin{array}{l}\text { D13Z1/ } \\
\text { D21Z1 }\end{array}$ & Oncor & $-13 / 21$ & $\begin{array}{l}47,+13 \text { two } \\
\text { cases }\end{array}$ & $\begin{array}{l}\text { False negative normal or false } \\
\text { positive monosomy } \\
21 / 13 \text { if normal }\end{array}$ & $\begin{array}{l}\text { Variations in signal } \\
\text { intensity not allowing } \\
\text { differentiation between } \\
\text { normal and abnormal } \\
\text { signals }\end{array}$ & Cacheux et al., 1994 \\
\hline $\begin{array}{l}\text { D13Z1/ } \\
\text { D21Z1 }\end{array}$ & Oncor & $-13 / 21$ & $\begin{array}{l}47,+21 \\
\text { three cases }\end{array}$ & $\begin{array}{l}\text { False negative normal or false } \\
\text { positive monosomy } 21 / 13 \\
\text { if normal }\end{array}$ & $\begin{array}{l}\text { Polymorphism or hybridization } \\
\text { insufficiency? }\end{array}$ & Verlinsky et al., 1995 \\
\hline $\begin{array}{l}\text { Cosmid contig } \\
21 \mathrm{q} 22.3\end{array}$ & $\begin{array}{l}\text { Klinger et al., } \\
1992\end{array}$ & -21 & $\begin{array}{l}47,+21 \text { two } \\
\text { cases }\end{array}$ & $\begin{array}{l}\text { False negative normal or false } \\
\text { positive monosomy } 21 \\
\text { if normal }\end{array}$ & $\begin{array}{l}\text { High background fluorescence } \\
\text { and autofluorescence } \\
\text { of microscope objective }\end{array}$ & Ward et al., 1993 \\
\hline
\end{tabular}


Table 5. (Continued)

\begin{tabular}{|c|c|c|c|c|c|c|}
\hline Probe used & Source of probe & FISH signals & $\begin{array}{l}\text { Case } \\
\text { karyotype }\end{array}$ & Potential misdiagnosis & Explanation given & Reference \\
\hline $\begin{array}{l}\text { Cosmid contig } \\
21 \mathrm{q} 22.3\end{array}$ & $\begin{array}{l}\text { Klinger et al., } \\
1992\end{array}$ & -21 & $\begin{array}{l}47,+21 \\
\text { three cases }\end{array}$ & $\begin{array}{l}\text { False negative normal or false } \\
\text { positive monosomy } 21 \\
\text { if normal }\end{array}$ & Maternal cell contamination & Ward et al., 1993 \\
\hline Not specified & Pinkel, 1986 & -21 & $\begin{array}{l}47,+21 \\
\text { three cases }\end{array}$ & $\begin{array}{l}\text { False negative normal or false } \\
\text { positive monosomy } 21 \\
\text { if normal }\end{array}$ & Pericentromeric deletion & Seres-Santamaria et al., 1993 \\
\hline L1.26 & Devilee, 1986 & -21 & $\begin{array}{l}47,+21 \\
\text { three cases }\end{array}$ & $\begin{array}{l}\text { False negative normal or false } \\
\text { positive monosomy } 21 \\
\text { if normal }\end{array}$ & Pericentromeric deletion & Bossuyt et al., 1995 \\
\hline L1.26 & Devilee, 1986 & -21 & $47,+21$ & $\begin{array}{l}\text { False negative normal or false } \\
\text { positive monosomy } 21 \\
\text { if normal }\end{array}$ & Maternal cell contamination & Bryndorf et al., 1997 \\
\hline $\begin{array}{l}\text { LSI } 21 \mathrm{q} 22.13- \\
21 \mathrm{q} 22.2\end{array}$ & Vysis & -21 & $47,+21$ & $\begin{array}{l}\text { False negative normal or false } \\
\text { positive monosomy } 21 \\
\text { if normal }\end{array}$ & Maternal cell contamination & Estabrooks et al., 1999 \\
\hline $\begin{array}{l}\text { LSI } 21 \mathrm{q} 22.13- \\
21 \mathrm{q} 22.2\end{array}$ & Vysis & +21 & $46, X X$ & $\begin{array}{l}\text { False positive trisomy } 21 / \text { trisomy } \\
13 \text { or false negative normal if } \\
\text { trisomy } 21 / \text { trisomy } 13\end{array}$ & $\begin{array}{l}\text { Unexplained (not cryptic } \\
\text { rearrangement or } \\
\text { vanishing twin) }\end{array}$ & Weremowicz et al., 2001 \\
\hline $\begin{array}{l}\text { LSI } 21 \mathrm{q} 22.13- \\
21 \mathrm{q} 22.2\end{array}$ & Vysis & +21 & $46, X Y$ & $\begin{array}{l}\text { False positive trisomy } 21 / \text { trisomy } \\
13 \text { or false negative normal if } \\
\text { trisomy } 21 / \text { trisomy } 13\end{array}$ & $\begin{array}{l}\text { Unexplained (not cryptic } \\
\text { rearrangement or } \\
\text { vanishing twin) }\end{array}$ & George et al., 2003 \\
\hline $\begin{array}{l}\text { Cosmid contig } \\
13 q 12.3\end{array}$ & Klinger et al., 1992 & -13 & $47,+13$ & $\begin{array}{l}\text { False negative normal or false } \\
\text { positive monosomy } 13 \text { if } \\
\text { normal }\end{array}$ & Unexplained & Ward et al., 1993 \\
\hline LSI 13q14 & Vysis & -13 & $47,+13$ & $\begin{array}{l}\text { False negative normal or false } \\
\text { positive monosomy } 13 \text { if } \\
\text { normal }\end{array}$ & $\begin{array}{l}\text { Maternal cell contamination, } \\
\text { poor hybridization }\end{array}$ & Estabrooks et al., 1999 \\
\hline LSI 13q14 & Vysis & -13 & $47,+13$ & $\begin{array}{l}\text { False negative normal or false } \\
\text { positive monosomy } 13 \text { if } \\
\text { normal }\end{array}$ & Large deletion at RBI locus? & Tepperberg et al., 2001 \\
\hline D18Z1 & Vysis & +18 & $46, X X$ or $X Y$ & $\begin{array}{l}\text { False positive trisomy } 18 \text { or false } \\
\text { negative normal if trisomy }\end{array}$ & $\begin{array}{l}\text { Cross hybridization to } \\
\text { chromosome } 22\end{array}$ & Thangavelu et al., 1998 \\
\hline $18 q 23$ & Klinger et al., 1992 & -18 & $47,+18$ & $\begin{array}{l}\text { False negative normal or false } \\
\text { positive monosomy } \\
\text { if normal }\end{array}$ & $\begin{array}{l}\text { High background fluorescence } \\
\text { and autofluorescence of } \\
\text { microscope objective }\end{array}$ & Ward et al., 1993 \\
\hline D18Z1 & Vysis & -18 & $47,+18$ & $\begin{array}{l}\text { False negative normal or false } \\
\text { positive monosomy } \\
\text { if normal }\end{array}$ & Maternal cell contamination & Estabrooks et al., 1999 \\
\hline D18Z1 & Vysis & -18 & $47,+18$ & $\begin{array}{l}\text { False negative normal or false } \\
\text { positive monosomy } \\
\text { if normal }\end{array}$ & $\begin{array}{l}\text { Weak signal from reduced } \\
\text { copy number of alpha } \\
\text { satellite sequences }\end{array}$ & Thilaganathan et al., 2000 \\
\hline
\end{tabular}




\begin{tabular}{|c|c|c|c|c|c|c|}
\hline D18Z1 & Vysis & -18 & $47,+18$ & $\begin{array}{l}\text { False negative normal } \\
\text { or false positive } \\
\text { monosomy if normal }\end{array}$ & $\begin{array}{l}\text { Weak signal from reduced } \\
\text { copy number of alpha } \\
\text { satellite sequences }\end{array}$ & Tepperberg et al., 2001 \\
\hline DXZ1 & Oncor & $+X$ & $\begin{array}{l}46, X X, t(15 ; Y) \\
\quad(p 11.2 ; q 11.21)\end{array}$ & False positive XXX & $\begin{array}{l}\text { Constitutionally abnormal } \\
\text { X chromosome }\end{array}$ & Verlinsky et al., 1998 \\
\hline DXZ1 & Oncor & $+X$ & $46, X Y$ & False positive $X X Y$ & $\begin{array}{l}\text { Cross hybridization to } \\
\text { chromosome } 19\end{array}$ & Winsor et al., 1999 \\
\hline DXZ1 & Vysis & $+X$ & $45, X$ & $\begin{array}{l}\text { False negative normal } \\
\text { or false positive XXX } \\
\text { if normal }\end{array}$ & $\begin{array}{l}\text { Extraembryonic cell } \\
\text { contamination in } \\
\text { specimen? Not } \\
\text { confirmed by } \\
\text { postmortem }\end{array}$ & Eiben et al., 1998 \\
\hline $\begin{array}{l}\text { Centromeric } \\
\mathrm{X} \text { fragment }\end{array}$ & Klinger et al., 1992 & $-X$ & $46, X X$ & $\begin{array}{l}\text { False positive } 45, \mathrm{X} \text { or } \\
\text { false negative normal } \\
\text { if } 47, \mathrm{XXX}\end{array}$ & Weak X signal & Bryndorf et al., 1996 \\
\hline DXZ1 & Vysis & $-X$ & $46, X X$ & $\begin{array}{l}\text { False positive } 45, X \text { or } \\
\text { false negative normal } \\
\text { if } 47, X X X\end{array}$ & Weak X signal & Tsuchiya et al., 2001 \\
\hline DYZ1 & Oncor & $+Y$ & $\begin{array}{l}46, X Y, t(15 ; Y) \\
\quad(p 11.2 ; q 11.21)\end{array}$ & False positive $47, \mathrm{XYY}$ & $\begin{array}{l}\text { Constitutionally abnormal Y } \\
\text { chromosome }\end{array}$ & Verlinsky et al., 1998 \\
\hline $\begin{array}{l}\text { PDP97 } \\
\text { derivative }\end{array}$ & Oncor & $-Y$ & $46, X Y$ & False positive $45, X$ & $\begin{array}{l}\text { Failure of Y probe to } \\
\text { hybridize }\end{array}$ & Ward et al., 1993 \\
\hline PHY2.1 & Pr. Cooke & $-Y$ & $46, \mathrm{X}, \operatorname{der}(Y p)$ & False positive $45, X$ & Abnormal Y chromosome & Mercier and Bresson, 1995 \\
\hline PDP97 & Wolfe, 1985 & $-Y$ & $47, X X Y$ & False negative & $\begin{array}{l}\text { Maternal cell contamination, } \\
\text { failure of } Y \text { probe to } \\
\text { hybridize }\end{array}$ & Bryndorf et al., 1997 \\
\hline DYZ3 & Vysis & $-Y$ & $46, X Y$ & False negative & $\begin{array}{l}\text { Weak Y signal, from reduced } \\
\text { copy number of alpha } \\
\text { satellite sequences }\end{array}$ & Tepperberg et al., 2001 \\
\hline
\end{tabular}

Constitutionally abnormal

hybridization to

specimen? No

fase positive $45, x$ or

if 47, XXX

se positive $45, X$ or

alse negative norma

False positive $45, \mathrm{X}$

False positive $45, X$

False negative 


\section{References}

Key references are identified by asterisks.

Adinolfi M, Sherlock J and Pertl B (1995) Rapid detection of selected aneuploidies by quantitative fluorescent PCR Bioessays 17 661-664

Bili C, Divane A, Apessos A, Konstantinos T, Apostolos A, loannis B, Periklis T and Florentin L (2002) Prenatal diagnosis of common aneuploidies using quantitative fluorescent PCR Prenatal Diagnosis 22 360-365

Bossuyt PJ, Van Tienen MN, De Gruyter L, Smets V, Dumon J and Wauters JG (1995) Incidence of low-fluorescence alpha satellite region on chromosome 21 escaping detection of aneuploidy at interphase by FISH Cytogenetics and Cell Genetics 68 203-206

Bryndorf T, Christensen B, Vad M, Parner J, Carelli MP, Ward BE, Klinger KW, Bang J and Philip J (1996) Prenatal detection of chromosome aneuploidies in uncultured chorionic villus samples by FISH American Journal of Human Genetics 59 918-926

Bryndorf T, Christensen B, Vad M, Parner J, Brocks V and Philip J (1997) Prenatal detection of chromosome aneuploidies by fluorescence in situ hybridization: experience with 2000 uncultured amniotic fluid samples in a prospective preclinical trial Prenatal Diagnosis 17 333-341

Cacheux V, Tachdjian G, Druart L, Oury JF, Serero S, Blot P and Nessmann C (1994) Evaluation of $X, Y, 18$, and 13/21 alpha satellite DNA probes for interphase cytogenetic analysis of uncultured amniocytes by fluorescence in situ hybridization Prenatal Diagnosis 14 79-86

Chen CP, Chern SR and Wang W (2000) Rapid determination of zygosity and common aneuploidies from amniotic fluid cells using quantitative fluorescent polymerase chain reaction following genetic amniocentesis in multiple pregnancies Human Reproduction 15 929-934

Chen CP, Chern SR and Wang W (2001) Fetal DNA analyzed in plasma from a mother's three consecutive pregnancies to detect paternally inherited aneuploidy Clinical Chemistry 47 937-939

Cheong Leung W, Chitayat D, Seaward G, Windrim R, Ryan G, Barrett J and Winsor EJ (2001) Role of amniotic fluid interphase fluorescence in situ hybridization (FISH) analysis in patient management Prenatal Diagnosis 21 327-332

Cirigliano V, Sherlock J, Conway G, Quilter C, Rodeck C and Adinolfi M (1999) Rapid detection of chromosomes $X$ and $Y$ aneuploidies by quantitative fluorescent PCR Prenatal Diagnosis 19 1099-1103

* Cirigliano V, Lewin P, Szpiro-Tapies S, Fuster C and Adinolfi M (2001) Assessment of new markers for the rapid detection of aneuploidies by quantitative fluorescent PCR (QF-PCR) Annals of Human Genetics 65 421-427

Cirigliano V, Ejarque M, Fuster C and Adinolfi M (2002) X chromosome dosage by quantitative fluorescent PCR and rapid prenatal diagnosis of sex chromosome aneuploidies Molecular Human Reproduction 81042 1045

Devilee P, Cremer T, Slagboom P, Bakker E, Scholl HP, Hager HD, Stevenson AF, Cornelisse CJ and Pearson PL (1986) Two subsets of human alphoid repetitive DNA show distinct preferential localization in the pericentric regions of chromosomes 13, 18, and 21 Cytogenetics and Cell Genetics 41 193-201

Donaghue C, Roberts A, Mann K and Ogilvie CM (2003) Development and targeted application of a rapid QF-PCR test for sex chromosome imbalance Prenatal Diagnosis 23 201-210

Eiben B, Trawicki W, Hammans W, Goebel R and Epplen JT (1998) A prospective comparative study on fluorescence in situ hybridization (FISH) of uncultured amniocytes and standard karyotype analysis Prenatal Diagnosis 18 901-906

Estabrooks LL, Hanna JS and Lamb AN (1999) Overwhelming maternal cell contamination in amniotic fluid samples from patients with oligohydramnios can lead to false prenatal interphase FISH results Prenatal Diagnosis 19 179-181

Evans MI, Henry GP, Miller WA et al. (1999) International, collaborative assessment of 146000 prenatal karyotypes: expected limitations if only chromosome-specific probes and fluorescent in situ hybridization are used Human Reproduction 14 1213-1216

Feldman B, Ebrahim SA, Hazan SL, Gyi K, Johnson MP, Johnson A and Evans MI (2000) Routine prenatal diagnosis of aneuploidy by FISH studies in high-risk pregnancies American Journal of Medical Genetics 90 233-238
Findlay I, Toth T, Matthews P, Marton T, Quirke P and Papp Z (1998) Rapid trisomy diagnosis (21, 18, and 13) using fluorescent PCR and short tandem repeats: applications for prenatal diagnosis and preimplantation genetic diagnosis Journal of Assisted Reproduction and Genetics 15 266-275

George AM, Oei P and Winship I (2003) False-positive diagnosis of trisomy 21 using fluorescence in situ hybridization (FISH) on uncultured amniotic fluid cells Prenatal Diagnosis 23 302-305

Grimshaw GM, Szczepura A, Hulten M, MacDonald F, Nevin NC, Sutton F and Dhanjal S (2003) Evaluation of molecular tests for prenatal diagnosis of chromosomes abnormalities Health Technology Assessment 7 156

Homer J, Bhatt S, Huang S and Thangavelu M (2003) Residual risk for cytogenetic abnormalities after prenatal diagnosis by interphase fluorescence in situ hybridization (FISH) Prenatal Diagnosis 23 566571

Jauniaux E, Cirigliano V and Adinolfi M (2003) Very early prenatal diagnosis on coelomic cells using quantitative fluorescent polymerase chain reaction Reproductive Biomedicine Online 6 494-498

Klinger K, Landes G, Shook D et al. (1992) Rapid detection of chromosome aneuploidies in uncultured amniocytes by using fluorescence in situ hybridization (FISH) American Journal of Human Genetics 51 55-65

Kuo WL, Tenjin H, Segraves R, Pinkel D, Golbus MS and Gray J (1991) Detection of aneuploidy involving chromosomes 13,18 , or 21 , by fluorescence in situ hybridization (FISH) to interphase and metaphase amniocytes American Journal of Human Genetics 49 112-119

Lapidot-Lifson Y, Lebo RV, Flandermeyer RR, Chung JH and Golbus MS (1996) Rapid aneuploid diagnosis of high-risk fetuses by fluorescence in situ hybridization American Journal of Obstetrics and Gynecology 174 886-890

Levett LJ, Liddle S and Meredith R (2001) A large-scale evaluation of amnio-PCR for the rapid prenatal diagnosis of fetal trisomy Ultrasound in Obstetrics and Gynecology 17 115-118

Lewin P, Kleinfinger P, Bazin A, Mossafa H and Szpiro-Tapia S (2000) Defining the efficiency of fluorescence in situ hybridization on uncultured amniocytes on a retrospective cohort of 27407 prenatal diagnoses Prenatal Diagnosis 20 1-6

Lichter $\mathbf{P}$ and Cremer T (2001) Chromosome analysis by non-isotopic in situ hybridization. In Human Cytogenetics: a Practical Approach Vol. II: Constitutional Analysis pp 157-190 Eds DE Rooney and BH Czepulkowski. IRL Press, Oxford, NewYork, Tokyo,

Lubin MB, Elashoff JD, Wang SJ, Rotter JI and Toyoda H (1991) Precise gene dosage determination by polymerase chain reaction: theory, methodology, and statistical approach Molecular and Cellular Probes 5 307-317

*Mann K, Fox SP, Abbs SJ, Yau SC, Scriven PN, Docherty Z and Ogilvie CM (2001) Development and implementation of a new rapid aneuploidy diagnostic service within the UK National Health Service and implications for the future of prenatal diagnosis Lancet 3581057 1061

Mansfield ES (1993) Diagnosis of Down syndrome and other aneuploidies using quantitative polymerase chain reaction and small tandem repeat polymorphisms Human Molecular Genetics 2 43-50

Marteau TM and Dormandy E (2001) Facilitating informed choice in prenatal testing: how well are we doing? American Journal of Medical Genetics 106 185-190

Mercier S and Bresson JL (1995) Prenatal diagnosis of chromosomal aneuploidies by fluorescence in situ hybridization on uncultured amniotic cells: experience with 630 samples Annales de Genetique 38 151-157

Miller WA and Peakman DC (1999) Prenatal cytogenetic diagnosis Journal of Medical Screening 6 1-2

Mizunoe T and Young SR (1992) Low fluorescence alpha satellite region yields negative result Prenatal Diagnosis 12 549-550

Morris A, Boyd E, Dhanjal S, Lowther GW, Aitken DA, Young J, Menzies AL, Imrie SJ and Connor JM (1999) Two years' prospective experience using fluorescence in situ hybridization on uncultured amniotic fluid cells for rapid prenatal diagnosis of common chromosomal aneuploidies Prenatal Diagnosis 19 546-551 
Ogilvie CM (2003) Prenatal diagnosis for chromosome abnormalities; past, present and future Pathologie Biologie 51 156-160

Pergament E, Chen PX, Thangavelu M and Fiddler M (2000) The clinical application of interphase FISH in prenatal diagnosis Prenatal Diagnosis 20 215-220

Pertl B, Yau SC, Sherlock J, Davies AF, Mathew CG and Adinolfi M (1994) Rapid molecular method for prenatal detection of Down's syndrome Lancet 343 1197-1198

Pertl B, Weitgasser U, Kopp S, Kroisel PM, Sherlock J and Adinolfi M (1996) Rapid detection of trisomies 21 and 18 and sexing by quantitative fluorescent multiplex PCR Human Genetics 98 55-59

Pertl B, Kopp S, Kroisel PM, Hausler M, Sherlock J, Winter R and Adinolfi M (1997) Quantitative fluorescence polymerase chain reaction for the rapid prenatal detection of common aneuploidies and fetal sex American Journal of Obstetrics and Gynecology 177 899-906

Pertl B, Kopp S, Kroisel PM, Tului L, Brambati B and Adinolfi M (1999) Rapid detection of chromosome aneuploidies by quantitative fluorescence PCR: first application on 247 chorionic villus samples Journal of Medical Genetics 36 300-303

Pinkel D, Straume T and Gray JW (1986) Cytogenetic analysis using quantitative, high-sensitivity, fluorescence hybridization Proceedings National Academy of Sciences USA 83 2934-2938

Quilter CR, Holman S, AL-Hammadi RM, Theodorides D, Hastings RJ and Delhanty JD (2001) Aneuploidy screening in direct chorionic villus samples by fluorescence in situ hybridisation: the use of commercial probes in a clinical setting BJOG $\mathbf{1 0 8} 215-218$

Robinson WP, McFadden DE, Barrett IJ, Kuchinka B, Penaherrera MS, Bruyere H, Best RG, Pedreira DA, Langlois S and Kalousek DK (2002) Origin of amnion and implications for evaluation of the fetal genotype in cases of mosaicism Prenatal Diagnosis 22 10761085

Schmidt W, Jenderny J, Hecher K, Hackeloer BJ, Kerber S, Kochhan L and Held KR (2000) Detection of aneuploidy in chromosomes X, Y, 13, 18 and 21 by QF-PCR in 662 selected pregnancies at risk Molecular Human Reproduction 6 855-860

Schouten JP, McElgunn CJ, Waaijer R, Zwijnenburg D, Diepvens F and Pals G (2002) Relative quantification of 40 nucleic acid sequences by multiplex ligation-dependent probe amplification Nucleic Acids Research 30 e57 (Abstract)

Seres-Santamaria A, Catala V, Cuatrecasas E and Villanueva R (1993) Fluorescent in situ hybridisation and Down's syndrome Lancet 3411544

Siffroi JP, Dupuy O, Joye N et al. (2000) Usefulness of fluorescence in situ hybridization for the diagnosis of Turner mosaic fetuses with small ring X chromosomes Fetal Diagnosis and Therapy 15 229-233

Strovel JW, Lee KD, Punzalan C and Schwarts S (1992) Prenatal diagnosis by direct analysis of uncultured amniotic fluid and chorionic villus cells using interphase fluorescence in situ hybridization (FISH) American Journal of Human Genetics 51 A12 (Abstract)

Tardy EP and Toth A (1997) Cross-hybridization of the chromosome 13/21 alpha satellite DNA to chromosome 22 or a rare polymorphism? Prenatal Diagnosis 17 487-488

*Tepperberg J, Pettenati MJ, Rao PN, Lese CM, Rita D, Wyandt H, Gersen S, White B and Schoonmaker MM (2001) Prenatal diagnosis using interphase fluorescence in situ hybridization (FISH): 2-year multi-center retrospective study and review of the literature Prenatal Diagnosis 21 293-301

Thangavelu M, Chen PX and Pergament E (1998) Hybridization of chromosome 18 alpha-satellite DNA probe to chromosome 22 Prenatal Diagnosis 18 922-925

Thein AT, Abdel-Fattah SA, Kyle PM and Soothill PW (2000) An assessment of the use of interphase FISH with chromosome specific probes as an alternative to cytogenetics in prenatal diagnosis Prenatal Diagnosis 20 275-280
Thilaganathan B, Sairam S, Ballard T, Peterson C and Meredith R (2000) Effectiveness of prenatal chromosomal analysis using multicolor fluorescent in situ hybridisation BJOG 107 262-266

Truong K, Gibaud A, Dupont JM, Guilly MN, Soussaline F, Dutrillaux B and Malfoy B (2003) Rapid prenatal diagnosis of Down syndrome using quantitative fluorescence in situ hybridization on interphase nuclei Prenatal Diagnosis 23 146-151

Tsuchiya K, Schueler MG and Dev VG (2001) Familial X centromere variant resulting in false-positive prenatal diagnosis of monosomy $\mathrm{X}$ by interphase FISH Prenatal Diagnosis 21 852-855

Verlinsky Y, Ginsberg N, Chmura M, Freidine $M$, White $M$, Strom C and Kuliev A (1995) Cross-hybridization of the chromosome 13/21 alpha satellite DNA probe to chromosome 22 in the prenatal screening of common chromosomal aneuploidies by FISH Prenatal Diagnosis $\mathbf{1 5}$ 831-834

Verlinsky Y, Ginsberg N, Chmura M, White M, Strom C and Kuliev A (1998) Detection of translocations involving the $\mathrm{Y}$-chromosome in prospective prenatal screening of common chromosomal aneuploidies by FISH Prenatal Diagnosis 18 390-392

Verma RS and Luke S (1992) Variations in alphoid DNA sequences escape detection of aneuploidy at interphase by FISH technique Genomics $\mathbf{1 4}$ 113-116

*Verma L, Macdonald F, Leedham P, McConachie M, Dhanjal S and Hultén M (1998) Rapid and simple prenatal DNA diagnosis of Down's syndrome Lancet 352 9-12

Voglino G, Marongiu A, Massobrio M, Campogrande M and Todros T (2002) Rapid prenatal diagnosis of aneuploidies Lancet 359442

Ward BE, Gersen SL, Carelli MP, McGuire NM, Dackowski WR, Weinstein M, Sandlin C, Warren R and Klinger KW (1993) Rapid prenatal diagnosis of chromosomal aneuploidies by fluorescence in situ hybridization: clinical experience with 4500 specimens American Journal of Human Genetics 52 854-865

Waters JJ and Waters KS (1999) Trends in cytogenetic prenatal diagnosis in the UK: results from UKNEQAS external audit, 1987-1998 Prenatal Diagnosis 19 1023-1026

Weier HU and Gray JW (1992) A degenerate alpha satellite probe, detecting a centromeric deletion on chromosome 21 in an apparently normal human male, shows limitations of the use of satellite DNA probes for interphase ploidy analysis Analytical Cellular Pathology 4 81-86

Weremowicz S, Sandstrom DJ, Morton CC, Niedzwiecki CA, Sandstrom MM and Bieber FR (2001) Fluorescence in situ hybridization (FISH) for rapid detection of aneuploidy: experience in 911 prenatal cases Prenatal Diagnosis 21 262-269

Winsor EJ, Silver MP, Theve R, Wright M and Ward BE (1996) Maternal cell contamination in uncultured amniotic fluid Prenatal Diagnosis $\mathbf{1 6}$ 49-54

Winsor EJ, Dyack S, Wood-Burgess EM and Ryan G (1999) Risk of falsepositive prenatal diagnosis using interphase FISH testing: hybridization of alpha-satellite X probe to chromosome 19 Prenatal Diagnosis 19 832-836

*Witters I, Devriendt K, Legius E, Matthijs G, Van Schoubroeck D, Van Assche FA and Fryns JP (2002) Rapid prenatal diagnosis of trisomy 21 in 5049 consecutive uncultured amniotic fluid samples by fluorescence in situ hybridisation (FISH) Prenatal Diagnosis 22 29-33

Wolfe J, Darling SM, Erickson RP, Craig IW, Buckle VJ, Rigby PW, Willard HF and Goodfellow PN (1985) Isolation and characterization of an alphoid centromeric repeat family from the human $\mathrm{Y}$ chromosome Journal of Molecular Biology 182 477-485

Yang CF, Tsai FJ, Wu JY, Shi YR, Lee CC and Tsai CH (1999) Rapid diagnosis of common aneuploidies by quantitative fluorescent polymerase chain reaction Acta Paediatrica Taiwanica 40 330-334 